\title{
Mapping habitats in a marine reserve showed how a 30-year trophic cascade altered ecosystem structure
}

\author{
Kévin Leleu ${ }^{a, b, c, 1}$, Brice Remy-Zephir ${ }^{a, d, 1}$, Roger Grace ${ }^{e}$, Mark J. Costello ${ }^{a, ~ *}$
}

\author{
a Leigh Marine Laboratory, University of Auckland, PO Box 349, Warkworth, New Zealand \\ ${ }^{b}$ IFREMER Brest, BP 70.29280 Plouzané, France \\ c Mediterranean Institute of Oceanography, Aix Marseille University, Campus de Luminy, Case 901, 13288 \\ Marseille Cedex, France \\ d Gardline Marine Sciences Pty Limited, Unit 2, 22 Blackly Row, Cockburn Central, Perth, WA 6164, Australia \\ ${ }^{\mathrm{e}}$ Postal Distribution Centre, Leigh, New Zealand \\ ${ }^{1}$ The first two authors are of equal rank.
}

*: Corresponding author : Mark J. Costello, Tel.: +64 93737599, email address : $\underline{\text { m.costello@auckland.ac.nz }}$

\begin{abstract}
:
Time-series studies have reported trophic cascades in land, freshwater and marine environments in many geographic areas. However, the spatial extent of habitats, a key metric of ecosystem structure, has not been mapped in these studies. Marine reserves can provide experimental, before-after and inside-outside (control-impacted), situations for assessing the impact of fishing on ecosystems. We mapped seabed habitats and their associated communities (biotopes) in New Zealand's oldest marine reserve for comparison with pre-reserve maps created about 30 years previously.
\end{abstract}

Areas grazed bare by sea urchins were entirely replaced in the centre of the reserve by kelp, or alga turf, an intermediate biotope between heavily grazed encrusting algae and lightly grazed kelp. Urchins declined following increased abundance and body size of spiny (rock) lobsters and fish (especially snapper) in the reserve but maintained bare rock outside. While this gradient in habitat change matched the gradient of predator abundance, it also matched the extent of reef habitat area. Thus the trophic cascade may be influenced by the effect of habitat on the abundance and behavioural interactions of urchins and their predators. Further ecosystem changes may arise should the abundance of mega-predators, such as seals, cetaceans and large sharks, increase in the region; if parasites become pathogenic; and/or when invasive species reach the reserve.

No-take marine reserves provide real-world experiments that show the importance of species in food webs, and the consequences of fishing for ecosystems. Because these changes in ecosystem structure may continue, and will vary with environment, climate and species distributions, reserves need to be permanent and replicated geographically. Habitat maps should be produced for all reserves to enable ecological changes in the ecosystem to be spatially quantified.

Keywords: Kelp forest; Ecosystem change; Predator release; Subtidal mapping; Urchin Barren; New Zealand; Lobster; Fish; Time-series 


\section{Introduction}

Marine reserves, or no-take Marine Protected Areas, can be considered experimental controls for human impacts, particularly commercial and recreational fisheries (Hughes et al., 2005; Russ and Alcala, 1998; Salomon et al., 2008; Steneck 1997, 1998; Tegner and Dayton 2000; Tetreault and Ambrose, 2007). Thus, it is not surprising that one of the first differences found between no-take marine reserves and outside areas is an increase in abundance and size of the fished species in the reserves (e.g. Claudet et al., 2008; Edgar and Stuart-Smith, 2009; Halpern 2003; Jones et al., 1993; Molloy et al., 2009). Often, these species are high-trophic level predators, such that changes in their abundance may have consequences for ecosystem structure through the trophic cascade" effect. Loss of biogenic habitat, one metric of ecosystem structure, will result in significant changes in the composition and abundance of associated species; for example for deep-sea coral (Costello et al., 2005) and seagrass (Phil et al., 2006) habitats. However, reviews have not looked at habitat differences inside and outside MPA (e.g. Lester et al., 2009; Molloy et al., 2009; Stewart et al., 2009), because of the lack of habitat maps.

Sampling of benthic habitats must be stratified by the dominant biotopes" present (Costello and Emblow 2005; Costello 2006; Harborne et al., 2008a), a term used to describe the combination of a distinct physical habitat and its dominant assemblage of species. Random sampling, without such stratification of benthic habitats, may overlook ecologically important biotopes that are small in area, or waste resources in collecting more samples than necessary in other habitats. Thus researchers typically stratify sampling to a particular habitat. The significance of their observations on species composition or abundance at the ecosystem level cannot be quantified unless they also map the extent of that habitat (Jones et al., 1993). For example, their samples may show no change in species composition or density while the biotope is decreasing in area, such as if sea urchins grazed a seaweed bed from its margins.

Subtidal reef communities in New Zealand are typical of most temperate areas in that they are dominated by large brown algae (Schiel, 1990), and sea urchins are a conspicuous component of many reefs, particularly in the north (Choat and Schiel, 1982; Schiel and Hickford, 2001). In the north east of New Zealand, grazing by the common sea urchin Evechinus chloroticus (Valenciennes, 1846) is important in influencing seaweed cover on reefs (Andrew and Choat, 1982; Shears and Babcock, 2002). When urchins are abundant, the rocks are grazed bare or are covered by crustose coralline algae. Such biotopes have a distinct community as they benefit grazing resistant plants and other grazers, such as crustose coralline algae and limpets (Fletcher, 1987).

Previous studies and ecological monitoring in the present study area investigated species abundance using quadrats, transects and baited underwater video (BUV) (e.g. Babcock et al., 1999; Shears and Babcock, 2004a, 2004b). These studies suggested that the increase in predatory snapper Pagrus auratus (Forster, 1801) (Sparidae), blue cod Parapercis colias (Forster, 1801) (Pinguipedidae), and spiny or rock lobster Jasus edwardsii (Hutton, 1875) (Palinuridae) had led to the recovery of kelp forest through reduced grazing by sea urchins (Shears and Babcock, 2002). Experiments have shown similar predator control of urchins in the north-east Pacific (Estes and Duggins, 1995), Mediterranean (Guidetti et al., 2004), Tasmania (Pedersen and Johnson, 2006; Barrett et al., 2009) and Western Australia (Cook and Vanderklift, 2011). However, a comparison with the pre-reserve situation (Ayling, 1978; Ayling et al., 1981) was necessary to determine if habitat change had occurred (Parsons et al., 2004). Parsons et al. (2004) thus mapped a small area in the centre of the reserve at a fine spatial resolution, but found that the area occupied by kelp had not changed, although its distribution may have become shallower, and the Urchin Barrens had been replaced by nonkelp seaweed communities. These studies and others led Langlois and Ballantine (2005) to propose four stages in the recovery of the present, and other marine reserves in north-eastern New Zealand, from fishing; namely responses by (1) top predators, (2) their prey, (3) biogenic 
habitat, and (4) that habitat associated fauna. In the present study area, these four stages in the recovery of benthic ecosystems from fishing were demonstrated by (1) the increase in abundance of snapper, blue cod, and lobster after 10 years, (2) increased predation on prey leading to decreased abundance of sea urchins on rocks and bivalves in sediments after 16 years, and (3) increased cover of macro-algae on rocks after 26 years. However, stage (3) had not been quantified by mapping and stage (4) remained unassessed.

In this study, we quantified the area occupied by benthic habitats before and after creation of New Zealand's first no-take Marine Reserve, and inside and outside the reserve at both times. Thus we conducted a Before-After Control-Impact (BACl) comparison with the reserve as the control for fishing impacts. We review studies on benthic productivity to assess whether the fourth stage in ecosystem recovery from fishing proposed by Langlois and Ballantine (2005) has occurred. The importance of habitat maps in monitoring ecosystem change, and lessons for assessing ecosystem stability under fishing pressure, are discussed.

\section{Study area and methods}

In the present study area, a no-take marine reserve in north-eastern New Zealand, scientific opinion was initially that the patchy nature of Urchin Barrens reflected recruitment variation and micro-habitat suitability, and that predators could not control sea urchins because small urchins find refuge in crevices, rock pools, gravel and under rocks (Andrews and Choat, 1982, 1985; Choat and Schiel, 1982; Shears and Babcock, 2007). The apparent lack of Urchin Barrens further south in New Zealand had been attributed to lower urchin abundance (Schiel, 1990), but recent surveys have found barrens throughout New Zealand (Shears and Babcock, 2007). A decade after the reserve was established, Cole et al. (1990) found increases in the abundance of large fish and spiny lobster, but no change in urchin abundance. Lobster size and abundance has remained at these levels since then (Pande et al., 2008). In 2004, lobster numbers and average size reached an all time high inside but numbers outside remained the same as before (15 versus 1 lobster per $500 \mathrm{~m}^{2}, 70 \% \geq 95 \mathrm{~mm}$ carapace length versus $46 \%$, Haggitt and Kelly, 2004). Scientific opinions were still that the lobsters were unlikely to control urchin abundance due to different micro-habitat preferences (Andrew and MacDiarmid, 1991). Indeed, urchin abundance and the presence of barrens does vary in relation to environmental conditions such as depth and wave exposure (Shears et al., 2008). By 1994, urchin abundance had decreased in the reserve and the occurrence of a trophic cascade was proposed (Cole and Keuskamp, 1998). That it took over a decade for urchin abundance to decrease may be because larger urchins escape predation and may live up to 10 years with a low natural mortality (Ebert and Southon, 2003). Quantifying the trend in predator and urchin abundance in the reserve is compromised by the lack of standardised monitoring until recent years. However, it appears that lobster abundance increased rapidly, within 4 years, urchins decreased after 12 years, and kelp increased after 15 years (Babcock et al., 2010; Salomon et al., 2009). At least since 1997, snapper, blue cod and red moki (Cheilodactylus spectabilis) are larger and more abundant inside the reserve than outside, although fish smaller than the legal size are similarly abundant (Taylor et al., 2005).

The Cape Rodney to Okakari Point Marine Reserve became the first marine reserve in New Zealand in November 1975 in response to requests from the University of Auckland's Leigh Marine Laboratory (Foster et al., 1983) (Figure 1). During the three following years, mapping of the intertidal and subtidal habitats provided the baseline for comparison against the present survey about 30 years later (Ayling, 1978; Ayling et al., 1981). The present study re-mapped the subtidal habitat of the reserve adapting methods used by Grace and Kerr (2005) (Appendix). We sampled more than the area covered in the first map but still the area sampled outside the reserve was less than sampled inside. We mapped habitats that covered more than a $5^{\star} 5 \mathrm{~m}$ area, as did the baseline survey (Ayling, pers. comm.), and as is standard for marine ecological surveys in other countries (Connor et al., 1997a, 1997b; Costello and 
Emblow, 2005). Small habitat patches, and microhabitats, will thus occur within the habitat areas mapped. All depths are reported as metres below Chart Datum. Species nomenclature follows the World Register of Marine Species (Appeltans et al., 2009). The biotope map was built up from a greater variety of survey methods than in the first study so as to improve accuracy and take less time (Appendix Figure A1). Thus we took aerial photographs and used side-scan sonar to define habitat boundaries, and underwater video and a diver towed on a manta board to save on scuba diving time. Habitats were classified based on previous studies of the area (Ayling, 1978; Ayling et al., 1981; Parsons et al., 2004; Shears et al., 2004) to ensure comparability between maps (Table 1).

To test the accuracy of the map, habitat data from 67 locations were obtained from two independent studies. A drop-down video sampled forty-two $1 \mathrm{~m}^{2}$ benthic images inside and outside the reserve, and 25 observations were recorded by scuba in August 2006. A $10 \mathrm{~m}$ radius was used around each sampled location to account for positioning errors. If the expected habitat was present in the $10 \mathrm{~m}$ zone, the map was considered $100 \%$ accurate. Map accuracy was determined by combining data on how the (a) map matched the field samples, and (b) field samples matched the map; methods termed user" and producer" accuracy (Congalton and Green, 1999). These tests found that the overall accuracy of the map was $86.6 \%$ (Table 2). Accuracy was high for the largest habitats, kelp forest $(97 \%)$ and sand $(92 \%)$, and the algal turf $(80-100 \%)$, but still over $50 \%$ for the smaller habitats (Table 2 ). The new habitat map was compared to that of Ayling et al. (1981), which was digitised using Arc GIS 9 (ESRI 1999). The western reserve boundary, indicated by Department of Conservation Boundary Markers, is $200 \mathrm{~m}$ inside the legal reserve boundary. The reserve was divided into five zones, each of about $1 \mathrm{~km}$ width, labelled $A, B, C, D$ and $E$ (Figure 2). Outside of the reserve, the zones $X_{1}$ (West) and $Y_{1}$ (East) refer to areas mapped in 1975-77 and the additional zones $X_{2}$ and $Y_{2}$ were mapped during the present study. The maps are available in png, pdf, and GIS compatible formats as an online Appendix 2 to this paper and from Remy-Zephir et al. (2012).

\section{Results}

Our 2006 measures of the area of reserve and its zones were within $1 \%$ of the baseline survey; i.e. 485 ha compared to 480 ha previously. Differences in the area of rock and sediment (largely sand) between surveys were also insignificant (Figure 3). Biotopes showed zonation with depth, namely:

(1) with mixed algae, Carpophyllum and algal turf in 0-10 m;

(2) Urchin Barrens in 3- $7 \mathrm{~m}$ depth;

(3) Ecklonia kelp from 5-18m; and

(4) Sponge Garden and Deep Reef below 18 m depth (Figure 2).

The area of kelp forest within the reserve in 2006 (60\% of rock area) was 49 hectares, more than twice that 30 years previously (28\%) (Figure 4). In comparison, the area of Urchin Barren within the reserve had declined from $31 \%$ (42 hectares) to $1 \%$, and of crustose coralline habitat from 25 to $3 \%$. Areas of shallow broken rock, classified as Carpophyllum zone and mixed algae for the 2006 map, increased from 5 to $17 \%$, and algal turf from 5 to $8 \%$. The area of Sponge Garden (5 to $4 \%$ ), Deep Reef (4 to $5 \%$ ), and sand and gravel on rock (3\%), did not change significantly. Combined, the bare rock habitats declined from 56 to $4 \%$, whereas seaweed dominated habitat increased from 38 to $77 \%$. 
Outside and west of the reserve, the algal turf increased by $18 \%$ while the Urchin Barren decreased by $13 \%$, and the kelp forest decreased from $31 \%$ to $26 \%$ (Figure 4). To the east of the reserve, the absence of shallow habitats on the baseline map did not provide enough data for a good comparison. In deeper water, we found decreased kelp forest and Deep Reef of $8 \%$ and $3 \%$ respectively.

In each zone of the reserve, the kelp forest, and to a lesser extent other seaweed biotopes, showed the greatest increase since the creation of the reserve (Tables 3 and 4). In 1977, the ratio of kelp forest to Urchin Barren in the reserve was near to 1. At the time of the present study, the kelp forest covered 75 times more of the hard substratum than Urchin Barren inside the whole reserve. In three zones within the reserve (A, C and D), no Urchin Barren areas were recorded in 2006. In zones B and E, the Urchin Barren areas were sparse and patchy. Outside of the reserve, to the west, the ratio of kelp forest to Urchin Barren was 1.2 in the baseline surveys, and remained around 1 at the time of the present study. Urchin barren was more extensive in zone $X_{2}$ than the Ecklonia forest (0.1). To the east, the coverage in kelp forest was still relatively high in $Y_{1}(14.6 \%)$ but much lower in $Y_{2}(2.7 \%)$ (Figure 4). Urchin barren was not mapped in 1975-77 for these areas. The central zones $C$ and $D$ showed most change. Thus there was a gradient in the replacement of Urchin Barrens by kelp from the centre of the reserve outwards. Inside the reserve, $72 \%$ of the Urchin Barren was replaced by kelp forest, $8 \%$ by alga turf, and $7 \%$ by mixed algae (Table 3 ). Outside and west of the reserve, $57 \%$ of the Urchin Barren was replaced by algal turf, while $16 \%$ remained Urchin Barren.

Taylor (1998) and Cowles et al. (2009) calculated the invertebrate density, biomass and productivity in the biotopes in the study area (Table 5). Taylor sampled all fauna $>$ retained by a $0.5 \mathrm{~mm}$ sieve but Cowles et al. excluded those $>8 \mathrm{~mm}$. In Taylor (1998), about $60 \%$ of the biomass on Urchin Barrens was due to urchins, and $26 \%$ grazing gastropod molluscs. These studies indicate that even when the $>8 \mathrm{~mm}$ size fauna, notably urchins, is excluded, the urchin barrens had lower density, biomass and productivity than the algal biotopes (Table 5).

\section{Discussion}

The most ecologically significant changes in habitat within the reserve were the almost total replacement of the Urchin Barren" by kelp forest", and to a lesser extent, other macro-algae. This resulted in a doubling of the area dominated by kelp forest, and a gradient of this effect from the centre of the reserve to the edges along the coast. The present study provides spatial data that supports the return of a natural trophic cascade in this ecosystem as proposed by Cole and Keuskamp (1998).

\subsection{Spatial gradients in habitat}

The density and size of predators of sea urchins has been found to be considerably higher in the centre of the reserve than the zones close to the boundaries and in adjacent fished areas (Kelly et al., 2000; Willis et al., 2000, 2003). Previous studies and our observations of fishing activity indicate high fishing pressure at the reserve boundaries may increase the contrast between trophic cascade effects within and immediately outside the reserve. However, the present study shows that the area of reef habitat shows a similar gradient. Habitat area may influence the abundance, composition and richness of reef associated species, including kelp, snapper, lobster and urchins. This may be because a larger area provides for better recruitment, more refugia from predators, a more diverse range of prey, or that a larger population size provides resilience against environmental and ecological pressures. Further mapping of habitats outside and inside marine reserves is necessary to determine whether area affects, or is neutral to, the trophic cascade. 


\subsection{Change in biotopes over time}

Parsons et al. (2004) found Urchin Barren in the reserve centre had been replaced by alga turf. The present study found that this area was now dominated by kelp, and that Urchin Barren was being replaced by algal turf in the west of the reserve; i.e. it had replaced $30 \%$ of the Urchin Barren in zone A, and $57 \%$ outside the reserve to the west. The algal turf was replacing Urchin Barren in the area $\mathrm{X}_{2}$ outside the signposted reserve but inside the official reserve boundary (Figure 4). This turf is dominated by the calcareous alga Corallina officinalis, a species likely to be more tolerant of grazing than the larger brown algae, suggesting this algal turf assemblage can be intermediate between Urchin Barren and kelp. Urchin-removal experiments have shown that a first response to a reduction in grazing pressure was an increase in the cover of this coralline turf (Shears and Babcock, 2002).

In the present study, there were no significant changes in the area of rock and sediment. Furthermore, the deeper habitats (-Deep Reef" and Sponge flat") do not seem to have changed since 1977. Similarly, long term monitoring of the rocky intertidal epifauna and epiflora in the centre of the reserve has not shown any trends associated with the reserve duration (Ballantine W. pers. comm.), and recent surveys of the intertidal (Costello, Unpublished results) indicate the habitats and communities there were similar to when surveyed in the 1970's. It thus appears that the change in biotopes to date has been restricted to the visually conspicuous habitats on shallow rocky reefs. However, changes to species densities may also have occured within other habitats due to the restoration of the food web. For example, in the sand adjacent to the reef of the present study area, there was a decreased abundance of large bivalves and heart urchins due to predation by lobsters, but no effect on smaller invertebrates (Langlois et al., 2005, 2006). Thus, less visually conspicuous communities not sampled in our study may also have changed in response to the cessation of fishing in the reserve.

\subsection{Fish and lobsters}

Fishing effort on the reserve boundary for both fish and lobsters would reduce predator abundance outside the reserve. However, it may not be expected to result in the Urchin Barren and macroalga habitats being distinct over a few metres at the reserve boundary (Figure 4). This may reflect predator behaviour, either that the boundaries of the reserve are coincident with their foraging territories, that they learn from the capture of con-specifics outside the boundary that it is an area to avoid, and/or that they feel safer closer to the increased number of conspecifics in the reserve. At least spiny lobsters may use chemoreception from conspecifics to avoid fished areas and move into unfished areas (Eggleston and Parsons, 2008). Prey can also show predator avoidance behaviour, as found for sea urchins in the presence of spiny lobsters (Matassa, 2010). Regardless of predator behaviour, snapper are resident to areas within a few hundred metres in the study area for at least several years (Egli and Babcock, 2004; Parsons et al., 2003, 2010; Willis et al., 2001). Similarly, $95 \%$ of tagged lobster (Jasus edwardsii) in a study in Tasmania moved less than $400 \mathrm{~m}$ over two years (Barrett et al., 2009), and they have been found to be similarly resident in the reserve studied here and elsewhere in New Zealand for at least a year (Freeman et al., 2009; Kelly and MacDiarmid, 2003). Evidence for a behavioural response of predators in relation to marine reserves occurred at nearby marine reserves, where the targeted fish populations increased in abundance and maximum size more rapidly than could be explained by individual growth within the reserve area (Willis et al., 2003; Denny et al., 2004). Studies on fish behaviour and movement are required to explain these observations. In contrast, regional fish stocks may not recover from fishing for over 15 years, because population increase requires success in spawning, egg and larva survival, and juvenile growth to adulthood (Hutchings, 2000). The increased recreational angling and lobster fishing pressure, that occurs on the reserve boundary, will also increase the contrast between fished species abundance inside and outside the reserve. However, the gradient of reef area will also 
influence fish abundance, and perhaps behaviour if larger reef areas are preferred habitat for dominant fish. Further mapping of benthic habitats in relation to predator and urchin abundance along the coast may clarify the significance of boundary and habitat area effects.

\subsection{Importance of habitat mapping}

The fundamental role of physical and biogenic habitats in determining what species occur in an area and their abundance is well-established. Thus, habitats can be used as surrogates of biodiversity in selecting areas as part of an MPA network (e.g. Dalleau et al., 2009; Harborne et al., 2008b; Parnell et al., 2006; Thrush et al., 2001; Ward et al., 1999), and quantifying available fish habitat (Ortiz and Tossot, 2008). In contrast to the inbuilt use of maps in land management, marine monitoring rarely includes changes in areal extent of habitats, perhaps because it has been assumed that these will not change significantly. Remarkably, previous studies on MPA have not quantified habitat or biotope change as indicators of ecosystem change. We were fortunate that scientists mapped the reserve's biotopes at the time it was created, although none of the changes now known were then predicted (Ballantine, 1989; Langlois and Ballantine, 2005). Our study shows the replacement of one biotope by another, which may have further consequences for biodiversity in the area. Other biotopes may also have changed but not been so evident. For example, in other MPA, in the absence of trawling and dredging, a rich epifaunal and infaunal community may recover that promotes sediment stability, retention of fine particles and silt, and creates a patchy muddy seabed (Thrush and Dayton, 2002; Kaiser et al., 2006). Megafauna such as crabs and fish may disturb the sediment by digging for prey or burrows for shelter, and thereby increase habitat diversity. Marine Reserves provide the best control for discovering how fishing and species interact to modify habitat and thus influence ecosystem structure. However, these benefits to conservation and scientific understanding of ecosystems can only be quantified if habitats are mapped.

\subsection{Consequences of habitat change}

Increased biodiversity is expected with the development of seaweed communities, because they provide three-dimensional habitat structure for mobile species (Anderson and Millar, 2004; Gratwicke and Speight, 2005; Willis and Anderson, 2003), increased surface area for sessile species, and additional food supply for grazers and detritivores. Over 73 species of mobile epifauna, primarily amphipod and isopod crustaceans, are associated with 10 species of brown algae in the study area (Taylor and Cole, 1994). Where phytoplankton production may be low, kelp may be an important source of carbon for invertebrates (Salomon et al., 2008), which in turn are food for fish. Indeed, in the absence of fish, even grazing amphipod crustaceans can significantly reduce kelp in the study area (Newcombe and Taylor, 2010). Thus, in some locations, Urchin Barrens may decrease fish production due to both loss of habitat and kelp-derived food. Thirty years of monitoring at the nearby Tawharanui Marine Reserve suggest that lobster biomass first increased once released from fishing, and secondarily when the kelp forest was restored (Grace, unpublished data). The consequences of fishing induced benthic trophic cascades for fishery production appear unstudied.

The density, biomass and estimated productivity of mobile macrofauna associated with seaweed biotopes (alga turf, Carpophyllum, and kelp) has been found to be several times greater than in Urchin Barrens (Table 5). These measures of biodiversity will have been decreased due to the trophic cascade in fished areas. This indicates that stage (4) of the trophic cascade proposed by Langlois and Ballantine (2005) has been reached. Future studies could investigate if species richness has also increased in the reserve, both as a product of new habitat, and greater area of seaweed dominated reefs. However, it is possible 
that this would be difficult to detect considering the small area of the reserve in relation to species dispersal, and habitat heterogeneity.

Fishing indirectly reduces parasite burdens by reducing fish density and the abundance of older fish (which tend to harbour more parasites than young fish) (Wood et al., 2010). Increasing species density in the reserve will facilitate parasite and disease transmission, forces that have been shown to affect ecosystem structure through their impacts on keystone species, such as diseases in sea urchins in the Caribbean, Mediterranean, NW Atlantic and California (Lafferty 2004; Sala et al., 1998; Steneck 1998), and digenean trematodes on grazing gastropods in the NW Atlantic (Wood et al., 2007). Fishing has also been implicated in the reduced diversity, prevalence and abundance of parasites on coral reef fish (Lafferty et al., 2008). While parasites and diseases have not been studied in the area, future surveillance needs to be vigilant for such developments. Indeed, pathogens may become a significant influence on the abundance of species as their host density increases at any trophic level. For example, an amphipod that burrows into older kelp plants, sometimes resulting in their death, can be abundant in the study area (Haggitt and Babcock, 2003).

Additional changes may yet arise should the abundance of mega-predators, such as cetaceans, large sharks, fur seals and sea lions increase, as was the case in pre-human times (Childerhouse and Gales, 1998; McGlone, 1989). Fur seals have returned to the region in the past few years as part of a northward recovery of formerly fished populations (pers. obs.), and up to eight individuals have been seen in the reserve at one time (Ivan Blackwell, Glass Bottom Boat, pers. comm.). The present reserve may be too small to accommodate megapredator populations, but if other conservation measures allow these species to increase in the region, then we may find further change in ecosystem structure due to trophic interactions. Alternatively, it may be that the large area over which these predators roam, and increased body size, age structure, and diversity of their prey in the ecosystem, may mean that these predators will not alter the trophic pyramid further. For example, the older demersal fish that contribute most to egg production, may also avoid predators better than the more numerous young fish.

Just as the changes observed to date were not predicted when the reserve was created, we make the above predictions with caution. Unexpected findings are not uncommon in ecology, especially where complex trophic interactions are involved (Doak et al., 2008). While 30 years is a significant time, and amongst the longest time-series for a marine reserve, it is within the generation-time of many marine species, including the top predators. Most fish populations take over 15 years to recover from over-fishing (Hutchings, 2000; Molloy et al., 2009), and Russ and Alcala (2004) found that after 18 years fish biomass was still increasing in two Phillipine reserves such that full recovery may take decades. The recovery stages proposed here are intended to create new research hypotheses. Different responses to fishing should be expected in different locations, reflecting how the local environmental conditions control the abundance of species. Thus, while the findings of the present study may be replicated elsewhere, they cannot be extrapolated to the entire coast. Biodiversity, in terms of both variety of species and biogenic habitats, can buffer against change due to disturbances whether natural or human in origin (De Ruiter et al., 2005; Tilman et al., 2006). Emerging threats include invasive species of crabs, seaweeds, bivalves and tunicates that are expanding their distribution in the region. These species would provide new food, predators, and/or habitat in the reserve, and may compete with native species for resources. However, we will only be aware of ecosystem changes, and be able to design experiments to explain them, if we have distribution maps of communities and their habitats, and continue ecological monitoring. Comparisons between no-take marine reserves and adjacent areas will further the understanding of how human activities directly impact individual species and habitats, and how indirect impacts happen through changes in ecosystem functioning and structure. 


\section{Acknowledgements}

We thank Tony Ayling, Bill Ballantine, Dan Egli, Tim Langlois, Alison MacDiarmid, Darren Parsons, Nick Shears, and Richard Taylor for helpful discussion and/or comments on this paper, and Richard Primack and anonymous referees for helpful suggestions that improved the paper. Gareth J. Williams and Mathew Cameron kindly provided their scuba observations of habitats in the study area, and Zeenatul Basher advice on ArcGIS file management.

\section{References}

Anderson, M.J., Millar, R.B., 2004. Spatial variation and effects of habitat on temperate reef fish assemblages in northeastern New Zealand. J. Exp. Mar. Biol. Ecol. 305, 191-221.

Andrew, N.L., Choat, J.H., 1982. The influence of predation and conspecific adults on the abundance of juvenile Evechinus chloroticus (Echinoidea: Echinometridae). Oecologia. 54, 80-87.

Andrew, N.L., Choat, J.H., 1985. Habitat related differences in the survivorship and growth of juvenile sea urchins. Mar. Ecol. Prog. Ser. 27, 155-161.

Andrew, N.L., MacDiarmid, A.B., 1991. Interrelations between sea urchins and spiny lobsters in northeastern New Zealand. Mar. Ecol. Prog. Ser. 70, 211-222.

Appeltans, W., Bouchet, P., Boxshall, G.A., Fauchald, K., Gordon, D.P., Hoeksema, B.W., Poore, G.C.B., Van Soest, R.W.M., Stöhr, S., Walter, T.C., Costello, M.J., (eds) 2009. World Register of Marine Species. www.marinespecies.org, Accessed 20 November 2009.

Ayling, A.M., 1978. Marine reserve survey. Bulletin 1. Leigh Laboratory, University of Auckland, New Zealand.

Ayling, A.M., Cumming, A., Ballantine, W.J., 1981. Map of shore and sub-tidal habitats of the Cape Rodney-Okakari Point Marine Reserve, North Island, New Zealand in 3 sheets, scale 1:2000. Department of Lands and Survey, Wellington, New Zealand.

Babcock, R.C., Kelly, S., Shears, N.T., Walker, J.W., Willis, T.J., 1999. Changes in community structure in temperate marine reserves. Mar. Ecol. Prog. Ser. 189, 125-134.

Babock, R.C., Shears, N.T., Alcala, A.C., Barrett, N.S., Edgar, G.J., Lafferty, K.D., McClanahan, T.R., Russ, G.R., 2010. Decadal trends in marine reserves reveal differential rates of change in direct and indirect effects. Proc. Natl. Acad. Sci. USA. 107, 18256-18261.

Ballantine, W.J., 1989. Marine reserves: lessons from New Zealand. Progress in Underwater Science. 13, 1-14.

Barrett, N., Buxton, C., Gardner, C., 2009. Rock lobster movement patterns and population structure within a Tasmanian Marine Protected Area inform fishery and conservation management. Mar. Freshwater Res. 60, 417-425.

Barrett, N., Buxton, C., Edgar, G.J., 2009. Changes in invertebrate and macroalgal populations in Tasmanian marine reserves in the decade following protection. J. Exp. Mar. Biol. Ecol. 370, 104-119.

Byrnes, J., Stachowicz, J.J., Hultgren, K.M., Hughes, A.R., Olyarnik, S.V., Thornber, C.S., 2006. Predator diversity strengthens trophic cascades in kelp forests by modifying herbivore behaviour. Ecology Letters. 9, 61-71.

Chang, F.H., Zeldis, J., Gall, M., Hall, J., 2003. Seasonal and spatial variation of phytoplankton assemblages, biomass, and cell size from spring to summer across the northeastern New Zealand continental shelf. J. Plankton Res. 25, 737-758.

Childerhouse, S., Gales, N., 1998. Historical and modern distribution and abundance of the New Zealand sea lion Phocarctos hookeri. N.Z. J. Zool. 25, 1-16.

Choat J.H., Schiel D.R. 1982. Patterns of distribution and abundance of large brown algae and invertebrate herbivores in subtidal regions of northern New Zealand. J. Exp. Mar. Biol. Ecol. 60: 129-162

Claudet, J., Osenberg, C.W., Benedetti-Cecchi, L., Domenici, P., Garcia-Charton, J-A., Pérez-

Ruzafa, Á., Badalamenti, F., Bayle-Sempere, J., Brito, A., Bulleri, F., Culioli, J-M., Dimech, M., 
Falcón, J.M., Guala, I., Milazzo, M., Sánchez-Meca, J., Somerfield, P.J., Stobart, B., Vandeperre, F., Valle, C., Planes, S., 2008. Marine reserves: size and age do matter. Ecology Letters. 11, 481-489.

Cole, R.G., Ayling, T.M., Creese, R.G., 1990. Effects of marine reserve protection at Goat Island, northern New Zealand. N.Z. J. Mar. Freshwat. Res. 24, 197-210.

Cole, R.G., Keuskamp, D. 1998. Indirect effects of protection from exploitation: patterns from populations of Evechinus chloroticus (Echinoidea) in northeastern New Zealand. Mar. Ecol. Prog. Ser. 173, 215-226.

Coma, R., Serrano, E., Linares, C., Ribes, M., Diaz, D., Ballesteros, E., 2011. Sea urchins predation facilitates coral invasion in a marine reserve. PLoS ONE 6(7): e22017.

Connell, S.D., Irving, A.D., 2008. Integrating ecology with biogeography using landscape characteristics: a case study of subtidal habitat across continental Australia. J. Biogeogr. 35, 1608-1621.

Connor, D.W., Brazier, D.P., Hill, T.O., Northen, K.O., 1997a. Marine Nature Conservation Review: marine biotope classification for Britain and Ireland. Vol. 1. Littoral biotopes. Version 97.06. Peterborough. Joint Nature Conservation Committee Report, No. 229.

Connor, D.W., Dalkin, M.J., Hill, T.O., Holt, R.H.F., Sanderson, W.G., 1997b. Marine Nature Conservation Review: marine biotope classification for Britain and Ireland. Vol. 2. Sublittoral biotopes. Version 97.06. Peterborough. Joint Nature Conservation Committee Report, No. 230.

Congalton, R., Green, K., 1999. Assessing the accuracy of remotely sensed data: principles and practices. Lewis Publishers, New York.

Cook, K., Vanderklift, M.A., 2011. Depletion of predatory fish by fishing in a temperate reef ecosystem leads to indirect effects on prey, bu not lower trohic levels. Mar. Ecol. Prog. Ser. 432, 195-205.

Costello, M.J., 2009. Distinguishing marine habitat classification concepts for ecological data management. Mar. Ecol. Prog. Ser. 397, 253-268.

Costello, M. J., Emblow, C., 2005. A classification of inshore marine biotopes, in: Wilson, J.G.Eds.), The intertidal ecosystem: the value of Ireland's shores. Royal Irish Academy, Dublin, pp. 25-35.

Costello, M.J., McCrea, M., Freiwald, A., Lundalv, T., Jonsson, L., Bett, B.J., Weering, T.V., de Haas, H., Roberts, J.M., Allen, D., 2005. Functional role of deep-sea cold-water Lophelia coral reefs as fish habitat in the north-eastern Atlantic, in: Freiwald, A., Roberts, J.M., Coldwater corals and ecosystems. Springer Verlag, Berlin Heidelberg, pp. 771-805.

Cowles, A., Hewitt, J.E., Taylor, R.B., 2009. Density, biomass and productivity of small mobile invertebrates in a wide range of coastal habitats. Mar. Ecol. Prog. Ser. 384, 175-185.

Dalleau, M., Andréfouët, S., Wabnitz, C. C., Payri, C., Wantiez, L., Pichon, M., Friedman, K., Vigliola, L., Benzoni, F., 2010. Use of habitats as surrogates of biodiversity for efficient coral reef conservation planning in Pacific ocean islands. Conserv. Biol. 24: 541-552.

Daskalov, G.M., Grishin, A.N., Rodionov, S., Mihneva, V., 2007. Trophic cascades triggered by overfishing reveal possible mechanisms of ecosystem regime shifts. Proc. Natl. Acad. Sci. USA. 104, 10518-10523.

Dayton, P.K., 1985. The structure and regulation of some South American kelp communities. Ecol. Monogr. 55, 447-468.

Dayton, P.K., Tegner, M.J., Parnell, P.E., Edwards, P.B., 1992. Temporal and spatial patterns of disturbance and recovery in a kelp forest community. Ecol. Monogr. 62, 421-445.

Denny, C.M., Willis, T.J., Babcock, R.C., 2004. Rapid recolonisation of snapper Pagrus auratus: Sparidae within an offshore island marine reserve after implementation of no-take status. Mar. Ecol. Prog. Ser. 272, 183-190.

De Ruiter, P.C., Wolters, V., Moore, J.C., Winemiller, K.O., 2005. Food web ecology: playing Jenga and beyond. Science. 309, 68-71.

Doak, D.F., Estes, J.A., Halpern, B.S., Jacob, U., Lindberg, D.R., Lovvorn, J., Monson, D.H., Tinker, M.T., Williams, T.M., Wootton, J.T., Carroll, I., Emmerson, M., Miocheli, F., Novak, M., 2008. Understanding and predicting ecological dynamics: are major surprises inevitable? Ecology. 89, 952-961. 
Ebert, T.A., Southon, J.R., 2003. Red sea urchins (Strongylocentrotus franciscanus) can live over 100 years: confirmation with A-bomb ${ }^{14}$ Carbon. Fish. Bull. 101, 915-922.

Edgar, G.J., Stuart-Smith, R.D., 2009. Ecological effects of marine protected areas on rocky reef communities-a continental-scale analysis. Mar. Ecol. Prog. Ser. 388, 51-62.

Egli, D.P., Babcock, R.C., 2004. Ultrasonic tracking reveals multiple behavioural modes of snapper (Pagrus auratus) in a temperate no-take marine reserve. ICES J. Mar. Sci. 61, 1137-1143.

Eggleston, D.B., Parsons, D.M. 2008., Disturbance-induced spill-in' of Caribbean spiny lobster to marine reserves. Mar. Ecol. Prog. Ser. 371, 213-220.

Estes, J., Duggins, D., 1995., Sea otters and kelp forests in Alaska. Ecol. Monogr. 65, 75-100.

Estes, J.A., Tinker, M.T., Williams, T.M., Doak, D.F., (1998) Killer whale predation on sea otters linking oceanic and nearshore ecosystems. Science. 282, 473-476.

Fletcher, W.J., 1987. Interactions among subtidal Australian sea urchins, gastropods, and algae: effects of experimental removals. Ecol. Monogr. 57, 89-109.

Foster, B., Rattenbury, J., Marbrook, J., 1983. A history of biology at the University of Auckland 1883-1983. University of Auckland, Auckland.

Frank, K.T., Petrie, B., Choi, J.S., Leggett, W.C., 2005. Trophic cascades in a formerly coddominated ecosystem, Science. 308, 1621-1623.

Freeman, D.J., MacDiarmid, A.B., Taylor, R.B., 2009. Habitat patches that cross marine reserve boundaries: consequences fo the lobster Jasus edwardsii. Mar. Ecol. Prog. Ser. 388, 159-167.

Goñi, R., Adlerstein, S., Alvarez-Berastegui, D., Forcada, A., Reñones, O., Criquet, G., Polti, S., Cadlou, G., Valle, C., Lenfant, P., Bonhomme, P., Pérez-Ruzaía, A., Sánchez-Lizaso, J.L., Garcia-Charton, J.A., Bernard, G., Stelzenmüller, V., Planes, S., 2008. Spillover from six western Mediterranean marine protected areas: evidence from artisanal fisheries. Mar. Ecol. Prog. Ser. 366, 159-174.

Grace, R., Kerr, V., 2005. Intertidal and subtidal habitats of Mimiwhangata Marine Park and adjacent shelf. Department of Conservation Research \& Development Series 201, Wellington, New Zealand.

Gratwicke, B., Speight, M.R., 2005. The relationship between fish species richness, abundance and habitat complexity in a range of shallow tropical marine habitats. J. Fish Biol. 66, 650-667.

Guidetti, P., 2006. Marine reserves reestablish lost predatory interactions and cause community changes in rocky reefs. Ecol. Appl. 16, 963-976.

Guidetti, P., Sala, E., 2007. Community-wide effects of marine reserves in the Mediterranean Sea. Mar. Ecol. Prog. Ser. 335, 43-56.

Guidetti, P., Bussoti, S., Boero, F. 2004. Evaluating the effects of protection on fish predators and sea urchins in shallow artificial rocky habitats: a case study in the northern Adriatic Sea. Mar. Environ. Res. 59 (2005), 333-348.

Haggitt, T.R., Babcock, R.C., 2003. The role of grazing by the lysianassid amphipod Orchomenella aahu in dieback of the kelp Ecklonia radiata in north-eastern New Zealand. Mar. Biol. 143, 1201-1211.

Haggitt, T.R., Kelly, S., 2004. Cape Rodney to Okakari Point Marine Reserve lobster monitoring programme: 2004 survey. Department of Conservation, Auckland. Accessed from http://www.doc.govt.nz/upload/documents/conservation/marine-and-coastal/marine-protected-

areas/report-on-lobster-monitoring.pdf on $1^{\text {st }}$ March 2012,

Halpern, B.S., 2003. The impact of marine reserves: do reserves work and does reserve size matter? Ecol. Appl. 13, S117-S137.

Halpern, B.S., Warner, R.R., 2002. Marine reserves have rapid and lasting effects. Ecology Letters. 5, 361-366.

Harborne, A.R., Mumby, P.J., Kappel, C.V., Dahlgren, C.P., Micheli, F., Holmes, K.E., Sanchirico, J.N., Broad, K., Elliott, I.A., Brumbaugh, D.R., 2008a. Reserve effects and natural variation in coral reef communities. J. Appl. Ecol. 45, 1010-1018. 
Harborne, A.R., Mumby, P.J., Kappel, C.V., Dahlgren, C.P., Micheli, F., Holmes, K.E., Brumbaugh, D.R., 2008b. Tropical coastal habitats as surrogates of fish community structure, grazing, and fisheries value. Ecol. Appl. 18, 1689-1701.

Harborne, A.R., Renaud, P.G., Tyler, E.H.M., Mumby, P.J., 2009. Reduced density of the herbivorous urchin Diadema antillarum inside a Caribbean marine reserve linked to decreased predation pressure by fishes. Coral Reefs 28, 783-791.

Harmelin-Vivien, M., Le Diréach, L., Bayle-Sempere, J., Charbonnel, E., Garcia-Charton, J.A., Ody, D., Pérez-Ruzaía, A., Reñones, O., Sánchez-Jerez, P., Valle, C., 2008. Gradients of abundance and biomass across reserve boundaries in six Mediterranean marine protected areas: evidence of fish spillover? Biol. Conserv. 141, 1829-1839.

Hernándex, J.C., Clemente, S., Sangil, C., Brito, A., 2007. Actual status of the sea urchin Diadema aff. Antillarum populations and macroalgal cover in marine protected areas compared to a highly fished area (Canary Islands - eastern Atlantic Ocean). Aquat. Conserv.: Mar. Freshwat. Ecosyst. 18, 1091-1108.

Hughes, T.P., Bellwood, D.R., Folke, C., Steneck, R.S., Wilson, J., 2005. New paradigms for supporting the resilience of marine ecosystems. Trends Ecol. Evol. 20, 380-386.

Hutchings, J.A., 2000. Collapse and recovery of marine fishes. Nature. 406, 882-885.

Jackson, J.B.C., Kirby, M.X., Berger, W.H., Bjorndal, K.A., Botsford, L.W., Bourque, B.J., Bradbury, R.H., Cooke, R., Erlandson, J., Estes, J.A., Hughes, T.P., Kidwell, S., Lange, C.B., Lenihan, H.S., Pandolfi, J.M., Peterson, C.H., Steneck, R.S., Tegner, M.J., Warner, R.R., 2001. Historical overfishing and the recent collapse of coastal ecosystems. Science. 293, 629638.

Jones, G.P., Cole, R.C., Battershill, C.N., 1993. Marine reserves: do they work?,in: Battershill, et al., (Eds.), Proceedings of the Second International Temperate Reef Symposium , 7-10 January 1992, Auckland, New Zealand. NIWA, Wellington, pp. 29-45.

Kaiser, M.J., Clarke, K.R., Hinz, H., Austen, M.C.V., Somerfield, P.J., Karakassis, I., 2006. Global analysis of response and recovery of benthic biotoa to fishing. Mar. Ecol. Prog. Ser. 311, 1-14.

Kelly, S., MacDiarmid, A.B., 2003. Movement patterns of mature spiny lobsters, Jasus edwardsii, from a marine reserve. N.Z. J. Mar. Freshwat. Res. 37, 149-158.

Kelly, S., Scott, D., MacDiarmid, A.B., Babcock, R.C., 2000. Spiny lobster, Jasus edwardsii, recovery in New Zealand marine reserves. Biol. Conserv. 92, 359-369.

Lafferty, K.D., 2004. Fishing for lobsters indirectly increases epidemics in sea urchins. Ecol. Appl. 14, 1566-1573.

Lafferty, K.D., Shaw, J.C., Kuris, A.M., 2008. Reef fishes have higher parasite richness at unfished Palmyra Atoll compared to fished Kirimati Island. EcoHealth. 5, 338-345.

Langlois, T.J., Ballantine, W.J., 2005. Marine ecological research in New Zealand : Developing predictive models through the study of no-take marine reserves. Conserv. Biol. 19: 1763-1770.

Langlois, T.J., Anderson, M.J., Babcock, R.C. 2005. Reef-associated predators influence adjacent soft-sediment communities. Ecology. 86, 1508-1519.

Langlois, T.J., Anderson, M.J., Babcock, R.C., 2006a. Inconsistent effects of reefs on different size classes of macrofauna in adjacent sand habitats. J. Exp. Mar. Biol. Ecol. 334, 269-282.

Langlois, T.J., Anderson, M.J., Babcock, R.C., Kato, S., 2006b. Marine reserves demonstrate trophic interactions across habitats. Oecologia. 147, 134-140.

Lester, S.E., Halpern, B.S., Groud-Colvert, K., Lubchenco, J., Ruttenberg, B.I., Gaines, S.D., Airame, S., Warner, R.R., 2009. Biological effects within no-take marine reserves: a global synthesis. Mar. Ecol. Prog. Ser. 384, 33-46.

Ling, S.D., Johnson, C.R., Frusher, S.D., Ridgway, K.R., 2009. Overfishing reduces resilience of kelp beds to climate-driven catastrophic phase shift. Proc. Natl. Acad. Sci. USA 106, 22341-22345.

Matassa, C.M., 2010. Purple sea urchins Strongylocentrotus purpuratus reduce grazing rates in response to risk cues from the spiny lobster Panulirus interruptus. Mar. Ecol. Prog. Ser. $400,283-288$. 
McClanahan, T.R., Shafir, S.H., 1990. Causes and consequences of sea urchin abundance and diversity in Kenyan coral reef lagoons. Oecologia. 83, 362-370.

McClanahan, T.R., Graham, N.A.J., Calnan, J.M., MacNeil, M.A., 2007. Toward pristine biomass: reef fish recovery in coral reef marine protected areas in Kenya. Ecol. Appl. 17, 1055-1067.

McGlone, M.S., 1989. The Polynesian settlement of New Zealand in relation to environmental and biotic changes. N. Z. J. Ecol. 12, 115-129.

Molloy, P.P., McLean, I.B., Côté, I.M., 2009, Effects of marine reserve age on fish populations: a global meta-analysis. J. Appl. Ecol. 46, 743-751.

Mumby, P.J., Dahlgren, C.P., Harborne, A.R., Kappel, C.V., Micheli, F., Brumbaugh, D.R., Holmes, K.E., Mendes, J.M., Broad, K., Sanchirico, J.N., Buch, K., Box, S., Stoffle, R.W., Gill, A.B., 2006. Fishing, trophic cascades, and the process of grazing on coral reefs. Science. 311, 98-101.

Mumby, P.J., Harborne, A.R., Williams, J., Kappel, C.V., Brumbaugh, D.R., Micheli, F., Holmes, K.E., Dahlgren, C.P., Paris, C.B., Blackwell, P.G., 2007. Trophic cascade facilitates coral recruitment in a marine reserve. Proc. Natl. Acad. Sci. USA. 104, 8362-8367.

Myers, R.A., Baum, J.K., Shepard, T.D., Powers, S.P., Peterson, C.H., 2007. Cascading effects of the loss of apex predatory sharks from a coastal ocean. Science. 315, 1846-1850.

Newcombe, E.M., Taylor, R.B., 2010. Trophic cascade in a seaweed-epifauna-fish food chain. Mar. Ecol. Prog. Ser. 408, 161-167.

Ortiz, D.M., Tissot, B.N., 2008. Ontogenic patterns of habitat use by reef-fish in a Marine Protected Area network: a multiscaled remote sensing and in situ approach. Mar. Ecol. Prog. Ser. 365, 217-232.

Pande, A., MacDiarmid, A.B., Smith, P.J., Davidson, R.J., Cole, R.G., Freeman, D., Kelly, S., Gardner, J.P.A., 2008. Marine reserves increase the abundance and size of blue cod and lobster. Mar. Ecol. Prog. Ser. 366, 147-158.

Parnell, P.E., Dayton, P.K., Lennert-Cody, C., Rasmussen, L.L., Leichter, J.J., 2006. Marine reserve design: optimal size, habitats, species affinities, diversity and ocean microclimate. Ecol. Appl. 16, 945-962.

Parravicini, V., Thrush, S.F., Chiantore, M., Morri, C., Croci, C., Bianchi, C.N., 2010. The legacy of past disturbance: chronic angling impairs long-term recovery of marine epibenthic communities from acute date-mussel harvesting. Biol. Conserv. 143, 2435-2440.

Parsons, D.M., Babcock, R.C., Hankin, R.K.S., Willis, T.J., Aitken, J.P., O‘Dor, R.K., Jackson, G.D., 2003. Snapper Pagrus auratus (Sparidae) home range dynamics: acoustic tagging studies in a marine reserve. Mar. Ecol. Prog. Ser. 262, 253-265.

Parsons, D.M., Shears, N.T., Babcock, R.C., Haggit, T.R., 2004. Fine-scale habitat change in a marine reserve, mapped using radio-acoustically positioned video transects. Mar. Freshwater Res. 55: 257-265.

Parsons, D.M., Morrison, M.A., Slater, M. J., 2010. Responses to marine reserves: decreased dispersion of the sparid Pagrus auratus (snapper). Biol. Conserv. 143, 2039-2048.

Pederson, H.G., Johnson, C.R., 2006. Predation of the sea urchin Heliocidaris erythrogramma by rock lobsters (Jasus edwardsii) in no-take marine reserves. J. Exp. Mar. Biol. Ecol. 336, 120-134.

Phil, L., Baden, S., Kautsky, N., Rönnback, P., Söderqvist, T., Troell, M., Wennhage, H., 2006. Shift in fish assemblage structure due to loss of seagrass Zostera marina habitats in Sweden. Estuar. Coast. Shelf Sci. 67, 123-132.

Pinnegar, J.K., Polunin, N.V.C., Francour, P., Badalamenti, F., Chemello, R., Harmelin-Vivien, M.-L., Hereu, B., Milazzo, M., Zabala, M., D‘Anna, G., Pipitone, C., 2000. Trophic cascades in benthic marine ecosystems: lessons for fisheries and protected-areas management. Environ. Conserv. 27, 179-200.

Remy-Zephir B., Leleu K, Grace R., Costello M.J. 2012. Geographical Information System (GIS) files of seabed habitats and biotope maps from Leigh Marine Reserve in 1977 and 2006. Accessed at http://hdl.handle.net/.

Russ, G.R., Alcala, A.C., 1998. Natural fishing experiments in marine reserves 1983-1993: community and trophic responses. Coral Reefs. 17, 383-397. 
Russ, G.R., Alcala, A.C., 2004. Marine reserves: long-term protection is required for full recovery of predatory fish populations. Oecologia. 138, 622-627.

Russ, G.R., Stockwell, B., Alcala, A.C., 2005. Inferring versus measuring rates of recovery in no-take marine reserves. Mar. Ecol. Prog. Ser. 292, 1-12.

Russ, G.R., Alcala, A.C., 2011. Enhanced biodiversity beyond marine reserve boundaries: the cup spillith over. Ecol. Appl. 21:241-250.

Sala, E., Boudouresque, C.F., Harmelin-Vivien, M. 1998. Fishing, trophic cascades, and the structure of algal assemblages: evaluation of an old but untested paradigm. Oikos. 82: 425439.

Salomon, A.K., Shears, N.T., Langlois, T.J., Babcock, R.C., 2008. Cascading effects of fishing can alter carbon flow through a temperate reef ecosystem. Ecol. Appl. 18, 1874-1887.

Salomon, A.K., Gaichas, S.K., Shears, N.T., Smith, J.E., Madin, E.M.P., Gaines, S.D., 2010. Key features and context-dependence of fishery-induced trophic cascades. Conserv. Biol. 24, 382-394.

Schiel, D.R., 1990. Macroalgal assemblages in New Zealand: structure, interactions and demography. Hydrobiologia. 192, 59-76.

Schiel, D.R., Hickford, M., 2001. Biological structure of nearshore rocky subtidal habitats in southern New Zealand. Science for Conservation. 182, 54pp.

Shears, N.T., Babcock, R.C., 2002. Marine reserves demonstrate top-down control of community structure on temperate reefs. Oecologia. 132, 131-142.

Shears, N.T., Babcock, R.C., 2003. Continuing trophic cascade effects after 25 years of notake marine reserve protection. Mar. Ecol. Prog. Ser. 246, 1-16.

Shears, N.T., Babcock, R.C., 2004a. Community composition and structure of shallow subtidal reefs in northeastern New Zealand. Science for Conservation. 245, 65p.

Shears, N.T., Babcock, R.C., 2004b. Indirect effects of marine reserve protection on New Zealand's rocky coastal marine communities. Science internal series 192. Department of Conservation, Wellington, New Zealand.

Shears, N.T., Babcock, R.C., 2007. Quantitative description of mainland New Zealand's shallow subtidal reef communities. Science for Conservation. 280, 126pp.

Shears, N.T., Babcock, R.C., Duffy, C.A.J., Walker, J.W., 2004. Validation of qualitative habitat descriptions commonly used to classify subtidal reef assemblages in north-eastern New Zealand. N.Z. J. Mar. Freshwat. Res. 38, 743-742.

Shears, N.T., Babcock, R.C, Salomon, A. K., 2008. Context dependent effects of fishing: variation in trophic cascades across environmental gradients. Ecol. Appl. 18, 1860-1873.

Steneck, R.S., 1997. Fisheries induced biological changes to the structure and function of the Gulf of Maine ecosystem, in Wallace, G.T.,, Braasch, E.F. (Eds.), Proceedings of the Gulf of Maine Ecosystem Dynamics Scientific Symposium and Workshop. Regional Association for Research on the Gulf of Maine, Hanover NH: RARGOM Report, 97-1, 153-167.

Steneck, R.S., 1998. Human influences on coastal ecosystems does overfishing create trophic cascades? Trends Ecol. Evol. 13, 429-430.

Stewart, G.B., Kaiser, M.J., Côté, I.M., Halpern, B.S., Lester, S.E., Bayliss, H.R., Pullin, A.S., 2009. Temperate marine reserves: global ecological effects and guidelines for future networks. Conservation Letters. 2, 243-253.

Taylor, R.B., Cole, R.G., 1994. Mobile epifauna on subtidal brown seaweeds in northeastern New Zealand. Mar. Ecol. Prog. Ser. 115, 271-282.

Taylor, R.B., Anderson, M.J., Egli, D., Usmar, N., Willis, T.J., 2005. Cape Rodney to Okakari Point Marine Reserve fish monitoring 2005: final report. Department of Conservation, Auckland. Accessed fromhttp://www.doc.govt.nz/upload/documents/conservation/marine-andcoastal/crop-fish-survey-2005.pdf on 1st March 2012.

Tegner, M.J., Dayton, P.K., 2000. Ecosystem effects of fishing in kelp forest communities. ICES J. Mar. Sci. 57, 579-589.

Tetreault, I., Ambrose, R.F., 2007. Temperate marine reserves enhance targeted but not untargeted fishes in multiple no-take areas. Ecol. Appl. 17, 2251-2267. 
Thrush, S.F., Hewitt, J.E., Funnell, G.A., Cummings, V.J., Ellis, J., Schultz, Talley, D., Norkko, A., 2001. Fishing disturbance and marine biodiversity: the role of habitat structure in simple soft-sediment systems. Mar. Ecol. Prog. Ser. 223, 277-286.

Thrush, S.F., Dayton, P.K., 2002. Disturbance to marine benthic habitats by trawling and dredging: implications for marine biodiversity. Annu. Rev. Ecol. Syst. 33, 449-473.

Tilman, D., Reich, P.B., Knops, J.M.H., 2006. Biodiversity and ecosystem stability in a decade-long grassland experiment. Science. 441, 629-632.

Ward, T.J., Vanderklift, M.A., Nicholls, A.O., Kenchington, R.A., 1999. Selecting marine reserves using habitats and species assemblages as surrogates for biological diversity. Ecol. Appl. 9, 691-698.

Watson, J., Estes, J.A., 2011. Stability, resilience, and phase shifts in rocky subtidal communities along the west coast of Vancouver Island, Canada. Ecol. Monogr. 81, 215-239.

Willis, T.J., Millar, R.B., Babcock, R.C. 2000. Detection of spatial variability in relative density of fishes: comparison of visual census, angling, and baited underwater video. Mar. Ecol. Prog. Ser. 198, 249-260.

Willis T.J., Parsons, D.M., Babcock, R.C., 2001. Evidence for long-term site fidelity of snapper (Pagrus auratus) within a marine reserve. N.Z. J. Mar. Freshwat. Res.35, 581-590.

Willis, T.J., Millar, R.B., Babcock, R.C. 2003. Protection of exploited fish in temperate regions: high density and biomass of snapper Pagrus auratus (Sparidae) in northern New Zealand marine reserves. J. Appl. Ecol. 40, 214-227.

Wood, C.L., Byers, J.E., Cottingham, K.L., Altman, I., Donahue, M.J., Blakeslee, A.M.H., 2007. Parasites alter community structure. Proc. Natl. Acad. Sci. USA. 104, 9335-9339.

Wood, C.L., Lafferty, K.D., Micheli, F., 2010. Fishing out marine parasites? Impacts of fishing on rates of parasitism in the ocean. Ecology Letters. 13,761-775.

Zeldis, J.R., 2004. New and remineralised nutrient supply and ecosystem metabolism on the northeastern New Zealand continental shelf. Cont. Shelf. Res. 24, 563-581. 
Table 1. Description of habitats and biotopes in this study. Numbers in descriptions are indicative rather than absolute, and taken from previous studies (Parsons et al., 2004; Shears et al., 2004). Biotopes were determined by identification of the dominant species. The Shallow Carpophyllum' and Mixed algae' habitats were both components of Ayling's (1978) Shallow broken rock" habitat. Urchin $\overline{\bar{b}}$ arren' was called rock flats", and alga turf' was called sediment covered rock flats' by Ayling (1978). Crustose coralline' is an adaptation from - Cobbles" in Ayling (1978) and Shears et al. (2004).

\begin{tabular}{|c|c|c|}
\hline Biotope (2006) & $\begin{array}{l}\text { Depth } \\
(\mathrm{m})\end{array}$ & Description \\
\hline $\begin{array}{l}\text { Shallow } \\
\text { Carpophyllum } \\
\text { (SC) }\end{array}$ & $<3$ & $\begin{array}{l}\text { Dominated by large brown fucoid algae (Carpophyllum maschalocarpum, C. } \\
\text { plumosum, C. flexuosum). A few short-stiped Ecklonia radiata ( }<1 \mathrm{~m}) \text { can be } \\
\text { present. Urchins (Evechinus choroticus) are low in abundance, cryptic or } \\
\text { found aggregated in depressions and crevices. The topography is usually } \\
\text { relatively broken. }\end{array}$ \\
\hline $\begin{array}{l}\text { Mixed algae } \\
\text { (MA) }\end{array}$ & $2-10$ & $\begin{array}{l}\text { Mixture of large brown algal species with no clear dominance of one species. } \\
\text { Urchins are usually low in abundance and cryptic but may be common. This } \\
\text { habitat often occured on an unbroken substratum with underlying rock } \\
\text { predominantly covered by turfing coralline algae. }\end{array}$ \\
\hline $\begin{array}{l}\text { Urchin barren } \\
\text { (UB) }\end{array}$ & 4-12 & $\begin{array}{l}\text { The average urchin density is }>2 . \mathrm{m}^{-2} \text {. The absence of large brown algae and } \\
\text { rocks covered by crustose coralline algae makes it look like a desert. Rock is } \\
\text { usually flat, but can be broken. }\end{array}$ \\
\hline $\begin{array}{l}\text { Algal turf } \\
\text { (AT) }\end{array}$ & $3-12$ & $\begin{array}{l}\text { More than } 30 \% \text { of the substrata is predominantly covered by turfing algae } \\
\text { (articulated corallines and other red turfing algae), with low number of brown } \\
\text { algae. Urchins are low in abundance and cryptic or absent. The presence of } \\
\text { sponges increases with depth. Rock is flat and the turf often traps sediment. }\end{array}$ \\
\hline $\begin{array}{l}\text { Ecklonia } \\
\text { forest } \\
\text { (EF) }\end{array}$ & $>5$ & $\begin{array}{l}\text { Almost entirely monospecific stands of mature Ecklonia radiata. Densities can } \\
\text { vary from sparse Ecklonia forest ( }<50 \% \text { cover) to dense Ecklonia forest. } \\
\text { Underlying substratum is often covered with coralline algae. Bryozoans, } \\
\text { hydroids, sponges and ascidians can live under the canopy. Urchins are rare } \\
\text { but can be very dense on the edge of the forest. Rock can be flat or broken; it } \\
\text { can also be possible to find an ephemeral layer of sand below the canopy } \\
\text { resulting from the movement of sediment during a storm. }\end{array}$ \\
\hline $\begin{array}{l}\text { Sponge Garden } \\
\text { (SG) }\end{array}$ & $>10$ & $\begin{array}{l}\text { Thick layer of fine sand overlying the rock. Sponges visually dominant. } \\
\text { Urchins are totally absent. Ecklonia radiata may be sparsely present in the } \\
\text { less deep areas. This habitat usually occurs on reef/sand interface. It is } \\
\text { however a highly patchy and transitional habitat between areas of reefs and } \\
\text { coarse sand ripples. }\end{array}$ \\
\hline $\begin{array}{l}\text { Deep Reef } \\
(\mathrm{DR})\end{array}$ & $>18$ & $\begin{array}{l}\text { Dominance of the sponges. Ecklonia radiata are sparse ( }<50 \% \text { cover). } \\
\text { Urchins are uncommon or absent. As the Sponge flat", this habitat can be } \\
\text { very patchy. } \\
\text { Usually found on high relief rocks such as greywacke, where sand can not } \\
\text { settle. }\end{array}$ \\
\hline $\begin{array}{l}\text { Cobbles and } \\
\text { crustose coralline } \\
\text { algae (CC) }\end{array}$ & All & $\begin{array}{l}\text { Mainly dominated by the crustose form of coralline algae, usually represented } \\
\text { on drifts of small boulders and cobbles }(<0.5 \mathrm{~m} \text { diam.), it can sometimes } \\
\text { occur on flat rocks. Large brown algae settlement is rare, but patches of } \\
\text { Ecklonia radiata or Carpophyllum sp. can occur around crevices. Urchins are } \\
\text { absent or rare. }\end{array}$ \\
\hline $\begin{array}{l}\text { Sediment } \\
\text { (SED) }\end{array}$ & All & $\begin{array}{l}\text { Coarse sand and shell hash that has formed } \sim 10 \mathrm{~cm} \text { high ripples. Debris such } \\
\text { as dead worm casts often fills the concave part of the sand ripple. Shell and } \\
\text { gravel are integrated in this habitat. }\end{array}$ \\
\hline $\begin{array}{l}\text { Sand and shell } \\
\text { gravel covered flat } \\
\text { rock (SF) }\end{array}$ & All & $\begin{array}{l}\text { A thin layer of sand on a flat hard substratum. Sometimes the rock appears } \\
\text { as the sediment moves, but the period of exposure is usually not long enough } \\
\text { to permit settlement on its surface. These areas can quickly change between } \\
\text { a sediment and rock appearance after storms. }\end{array}$ \\
\hline
\end{tabular}




\begin{tabular}{|c|c|c|c|c|c|c|c|c|c|}
\hline \multirow[t]{2}{*}{ Habitat on map } & \multicolumn{7}{|c|}{ Habitats in the field } & \multirow[t]{2}{*}{ Total data points } & \multirow[t]{2}{*}{ User accuracy (\%) } \\
\hline & DR & Kelp & MA & Sed & $S G$ & AT & UB & & \\
\hline Deep Reef (DR) & 2 & & & 1 & 2 & & & 5 & 40 \\
\hline Eckonis kelp forest & & 29 & 1 & & & & & 30 & 97 \\
\hline Mixed algae (MA) & & & 0 & & & & & 0 & 0 \\
\hline Sediment & 1 & & & 22 & & & 1 & 24 & 92 \\
\hline Sponge Garden (SG) & & & & 1 & 0 & & & 1 & 0 \\
\hline Algal turf (AT) & & & 1 & & & 4 & & 5 & 80 \\
\hline Urchin Barren (UB) & & 1 & & & & & 1 & 2 & 50 \\
\hline Total data points & 3 & 30 & 2 & 24 & 2 & 4 & 2 & 67 & \\
\hline Producer accuracy (\%) & 67 & 97 & 0 & 92 & 0 & 100 & 50 & & 87 \\
\hline
\end{tabular}

Table 3. Percentage of habitat in 2006 that had replaced the Urchin Barren mapped in 197577 (Ayling et al., 1981). Sponge Garden and Deep Reef habitats that did not replace barrens are omitted.

\begin{tabular}{|c|c|c|c|c|c|c|c|c|}
\hline & $\begin{array}{r}\text { Ecklon } \\
i a \\
\text { forest }\end{array}$ & $\begin{array}{r}\text { Shallow } \\
\text { Carpophyllum }\end{array}$ & $\begin{array}{l}\text { Mixed } \\
\text { algae }\end{array}$ & $\begin{array}{r}\text { Alga } \\
\text { turf }\end{array}$ & $\begin{array}{r}\text { Cobbles } \\
\& \\
\text { corraline }\end{array}$ & $\begin{array}{l}\text { Urchin } \\
\text { barren }\end{array}$ & $\begin{array}{r}\text { Sand, } \\
\text { shell } \\
\text { gravel } \\
\text { over flat } \\
\text { rock }\end{array}$ & Sediment \\
\hline $\mathrm{A}$ & 17 & 14 & 18 & 30 & 7 & 0 & 9 & 7 \\
\hline B & 86 & 2 & 4 & 4 & 1 & 1 & 2 & 0 \\
\hline C & 62 & 3 & 9 & 12 & 0 & 0 & 10 & 3 \\
\hline D & 58 & 3 & 4 & 0 & 1 & 0 & 0 & 4 \\
\hline$E$ & 77 & 1 & 10 & 0 & 2 & 4 & 0 & 6 \\
\hline West $\mathrm{X}_{1}$ & 10 & 12 & 4 & 57 & 0 & 16 & 0 & 0 \\
\hline $\begin{array}{l}\text { All } \\
\text { reserve }\end{array}$ & 72 & 4 & 7 & 8 & 1 & 1 & 4 & 3 \\
\hline
\end{tabular}


Table 4. The actual total (inside and outside the reserve) surface area (ha) of the habitats between 1977 and 2006 as mapped in Figure 2 and described in Table 1.

1977

2006

$\begin{array}{lrr}\text { Ecklonia kelp forest } & 45.9 & 96.1 \\ \text { Mixed algae, shallow Carpophyllum } & 35.1 & 30.2 \\ \text { Urchin barrens } & 44.7 & 4.5 \\ \text { Algal turf, crustose, coralline } & 12.0 & 17.1 \\ \text { Sponge Garden } & 7.1 & 6.6 \\ \text { Deep Reef } & 6.6 & 8.0 \\ \text { Sand, shell, pebbles , gravel } & 836.0 & 965.8\end{array}$

Table 5. The density, biomass and production of macro-invertebrates on the benthic biotopes in the study area. Data from (A) Taylor (1998), and (B) Cowles et al. (2009) which excludes fauna $>8 \mathrm{~mm}$ and thus large sea urchins.

\begin{tabular}{|c|c|c|c|c|c|c|c|}
\hline & Source & $\begin{array}{l}\text { Density } \\
\text { Individuals }\end{array}$ & $\begin{array}{l}\text { Biomass } \\
\text { g AFDW }\end{array}$ & $\begin{array}{l}\text { Productivity } \\
\text { mg AFDW }\end{array}$ & $\begin{array}{l}\text { Density } \\
\text { Ratio to }\end{array}$ & $\begin{array}{l}\text { Biomass } \\
\text { Urchin Barre }\end{array}$ & $\begin{array}{l}\text { Productivity } \\
\text { en }\end{array}$ \\
\hline & & $\left(m^{-2}\right)$ & $\left(m^{-2}\right)$ & $\left(m^{-2} d^{-1}\right)$ & & & \\
\hline \multirow{2}{*}{$\begin{array}{l}\text { Carpophyllum } \\
\text { forest }\end{array}$} & A & 203,310 & 31.70 & 482 & 8.3 & 0.8 & 4.1 \\
\hline & B & 15,144 & 2.14 & 42 & 5.1 & 8.9 & 7.0 \\
\hline \multirow[t]{2}{*}{ Algal turf } & A & 159,086 & 26.42 & 420 & 6.5 & 0.6 & 3.6 \\
\hline & $\mathrm{B}$ & 125,796 & 8.80 & 221 & 42.6 & 36.7 & 36.8 \\
\hline \multirow[t]{2}{*}{ Ecklonia forest } & A & 71,122 & 21.30 & 208 & 2.9 & 0.5 & 1.8 \\
\hline & $\mathrm{B}$ & 6,088 & 1.28 & 21 & 2.1 & 5.3 & 3.5 \\
\hline \multirow[t]{2}{*}{ Urchin Barren } & A & 24,428 & 42.16 & 117 & - & - & - \\
\hline & B & 2,951 & 0.24 & 6 & - & - & - \\
\hline
\end{tabular}


Figure 1. Map of the Hauraki Gulf, north-eastern New Zealand, indicating the location of the study area at Leigh.

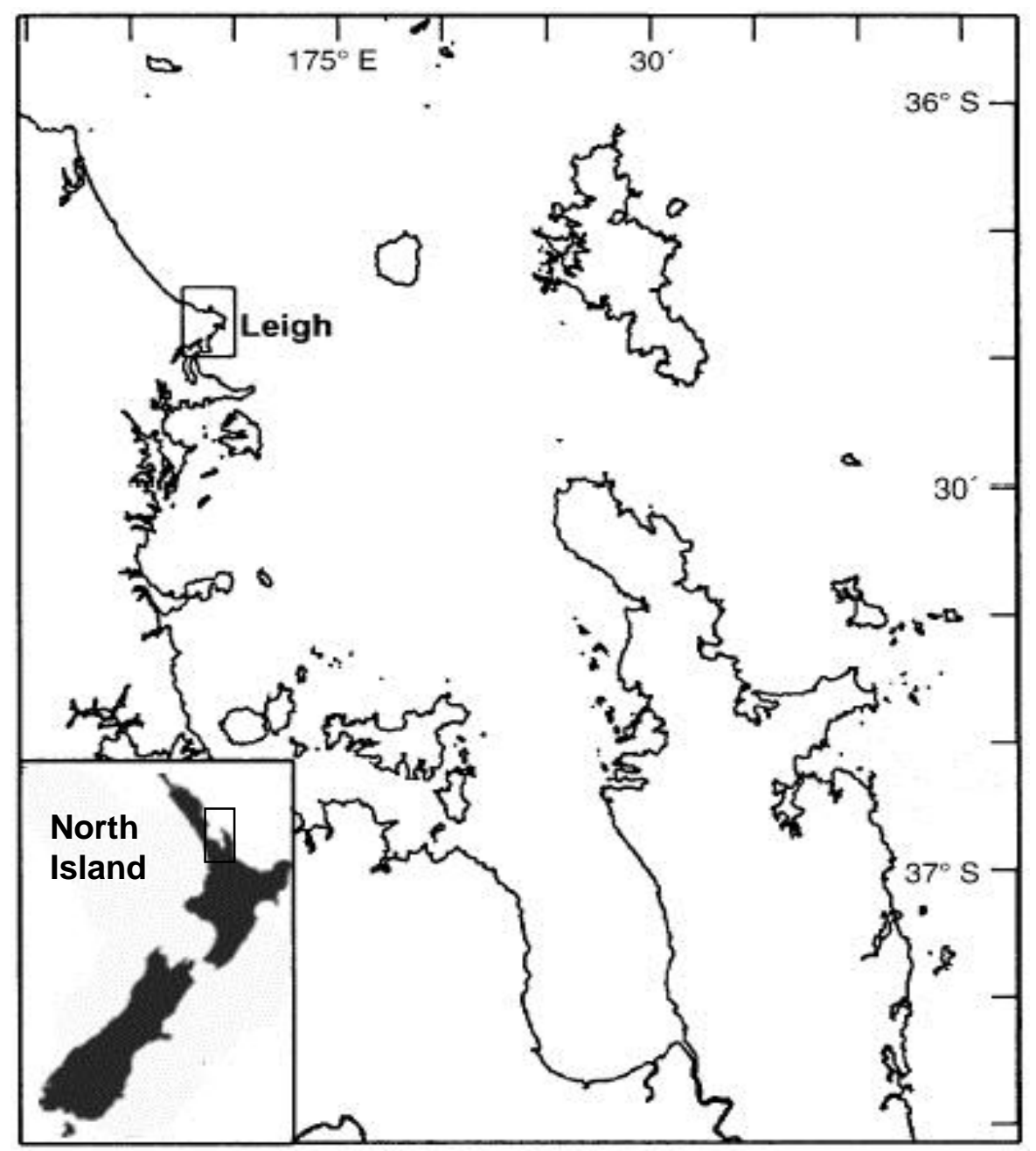


Figure 2. Maps of the benthic habitats in the marine reserve in 1977 (lower) and 2006 (upper). Land is stippled, sediment (sand, gravel, cobble) yellow, deep-reef dark blue, Sponge Garden orange, kelp green, Urchin Barren pale blue, crustose algae pink. mixed alga turf and Carpophyllum red, and intertidal grey. Some habitats occupying a small area (Table 1) have been combined for clarity.

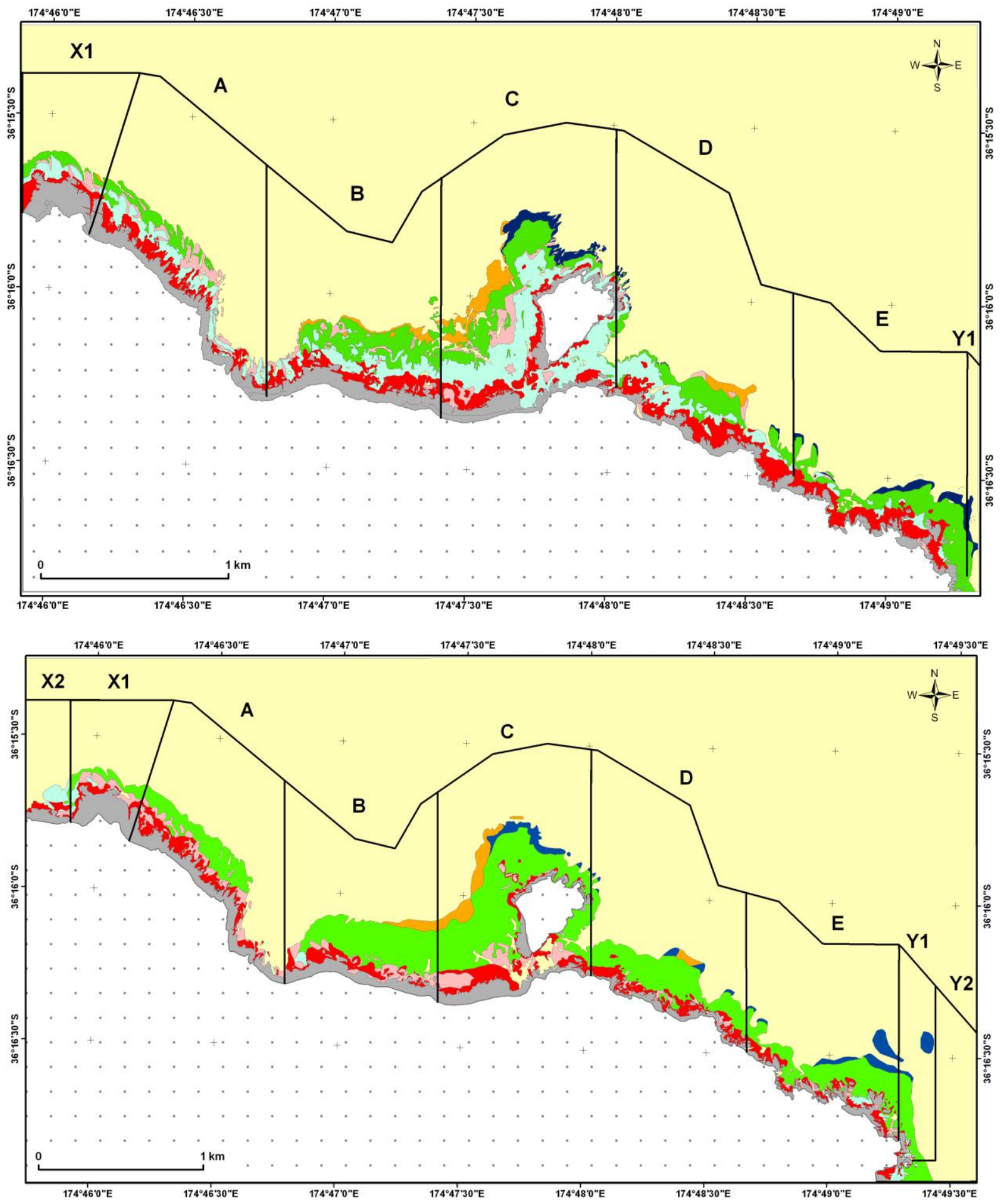


Figure 3. The area of rock from 1977 (solid bar) to 2006 (hollow bar) inside (A to E) and outside $(X, Y)$ the reserve.

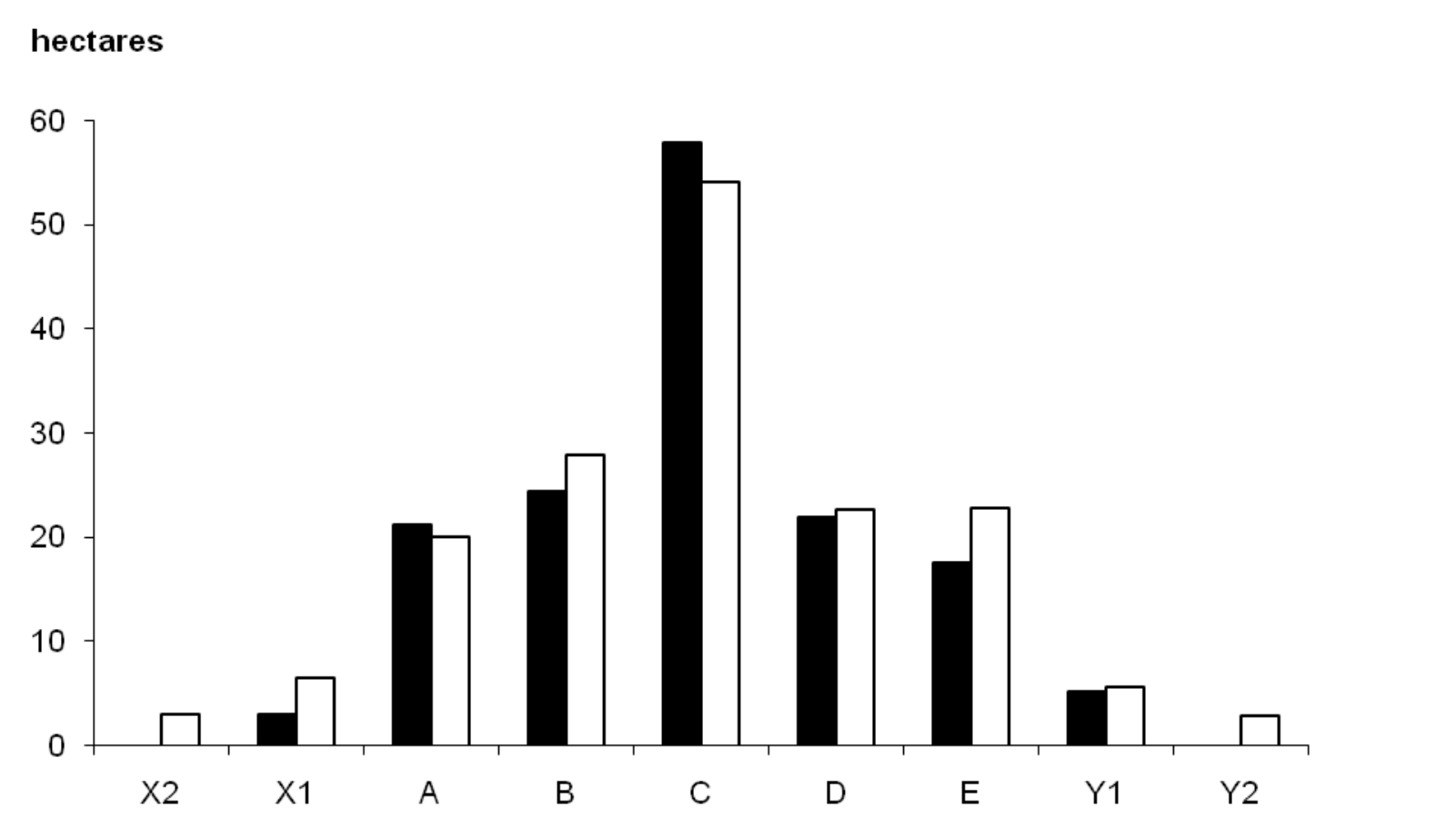

Figure 4. Change in the percentage of the study area occupied by kelp forest (solid bars) and Urchin Barrens (hollow bars) in each section of the study area (Figure 3) from 1977 to 2006, and the reserve as a whole (A-E).

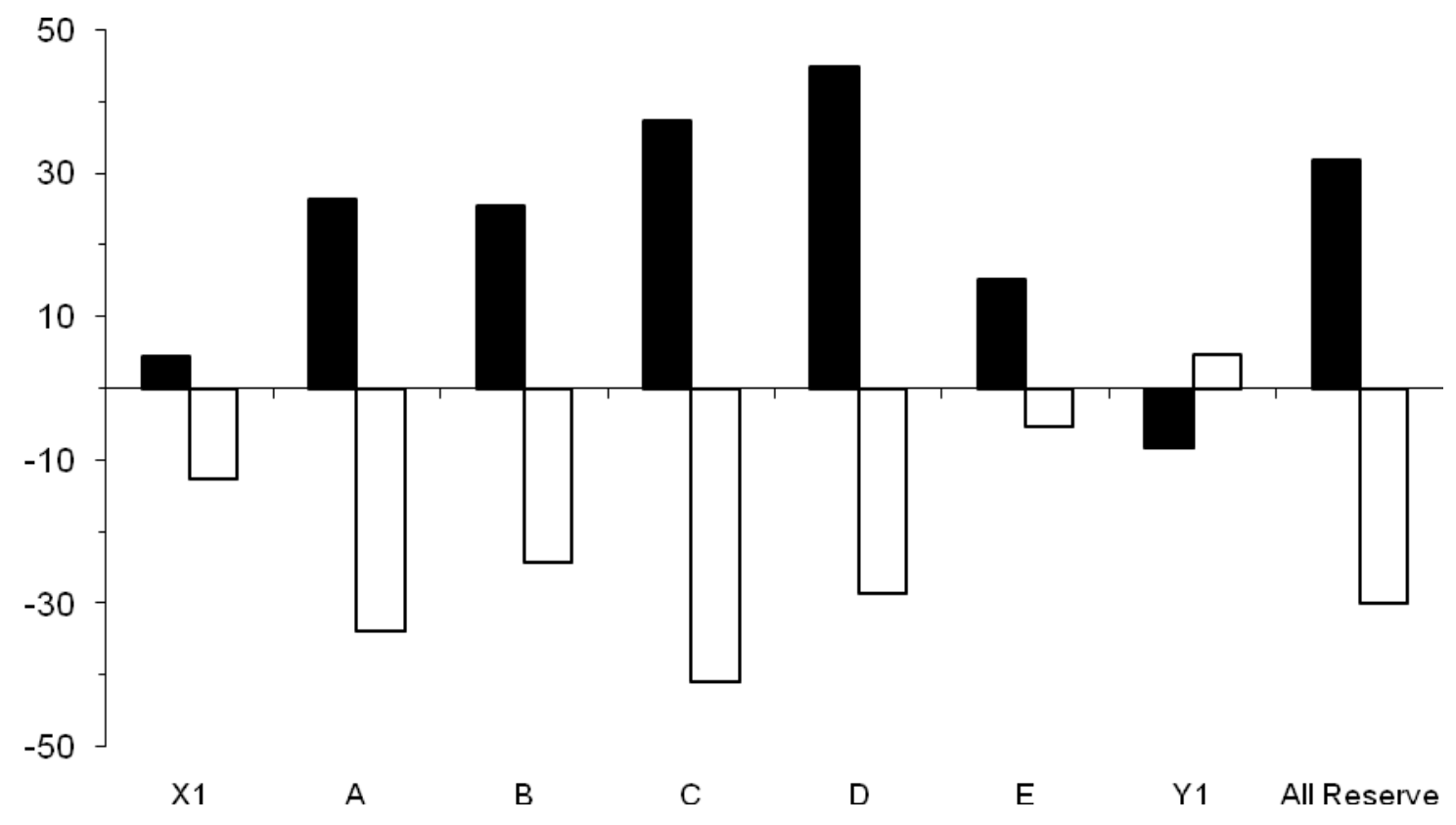




\section{APPENDIX: Details of survey methods}

The coastline was digitised from aerial photographs geo-referenced with a Garmin ETREX handheld Global Positioning System (GPS) receiver. The seabed topography, and the boundary between the rocky reef and sand, were distinguished using a Humminbird 987-C SI Side Scan Sonar. This acoustic survey comprised of 73 transects perpendicular to the shore with a swath of $100 \mathrm{~m}$ at each side of the sonar, separated by approximately $75 \mathrm{~m}$ to ensure overlap, and 34 transects with a swath of $50 \mathrm{~m}$ parallel to the coast (Figure A1a). These transects were positioned in the field using a Humminbird chart plotter GPS receiver on the 19th and 21st April 2006 and the 7 th of May 2006. The total area surveyed was approximately 714 hectares. A digital video footage from the display screen of the side scan sonar recorded seabed imagery aswell as position, depth and time. Consecutive still images were then extracted from the video, georeferenced and finally overlayed on the map. In deeper waters, side scan sonar surveys give an accuracy of $+/-10 \mathrm{~m}$ for the discontinuity between rocky reef and sediments. In water less than $15 \mathrm{~m}$ deep, the accuracy was estimated to be less than $10 \mathrm{~m}$. However, overall accuracy was limited by the georeferencing error of 5 to $7 \mathrm{~m}$.

Aerial photographs were obtained on $16^{\text {th }}$ June 2006 during settled weather and calm sea conditions with no wind or swell (Figure A1b). The co-occurrence of low water with a high angle of the sun (10:29 a.m) provided an optimal visual penetration into the water. The aircraft used had a camera port in the floor to provide approximately vertical photographs, that were later georeferenced. The shallow habitat boundaries were traced from the aerial photographs to a depth of approximately $10-12 \mathrm{~m}$, and about $100 \mathrm{~m}$ from the shore. These habitats were verified by snorkelling to $10 \mathrm{~m}$ depth. It was possible to cover approximately $500 \mathrm{~m}$ of coastline in 2 hours with two snorkellers. The snorkellers recorded information on waterproof paper on which the coastline and the expected habitat contours were drawn. Particular landmarks on the shore were used for orientation and to locate the habitats on the map.

A towed manta-board was used to validate information from the sonar and map habitats in deeper waters $(>12 \mathrm{~m})$, particularly in the more topographically complex parts of the reserve on the 9th and 10th June 2006. This rapid survey method allowed a greater distance to be covered than by scuba. The manta-board consisted of a simple flat piece of marine plywood attached to a bridle with a thin tow line attached to the stern of a boat. A scuba diver was towed at about 2 knots $50 \mathrm{~m}$ behind the boat and noted the time when the habitat changed on a waterproof writing pad attached to the board. The diver and the crew of the boat had synchronised stop-watches and the geographic position was recorded, using a Garmin ETREX handheld GPS receiver on the boat every 30 seconds. The diver observations could be positioned on the map by correcting the positions by the layback distance between the diver and boat.

Habitats were mapped using Drop Down Video (DDV), comprised of a Sony video camera with a wide angle lens mounted in a simple, robust housing built from a recycled scuba cylinder and plexiglas sheet material. The angle of the housing was set at ca. $45^{\circ}$. A weight was attached $1 \mathrm{~m}$ below the housing and a series of floats were attached above the housing. When the bottom weight touched the sea floor the housing would rotate in a semi-circle allowing a view of the habitat surrounding the drop site. The area of the benthos observed could also be increased by bouncing the unit along the bottom for a short distance. We left the video on the bottom for approximately 1 min in locations chosen using the sonar images. This video sampled: all the major physical habitat types; areas where it was likely that habitat boundaries were not currently covered by the survey; reef areas where major biological boundaries were likely to occur; boundaries between the high relief and low relief rocks; and boundaries between rock and sediment substrata. A total of 195 drops with 1-minute on the seabed were sampled on $7^{\text {th }}, 10^{\text {th }}$ and $13^{\text {th }}$ May 2006 , along transects separated by $150 \mathrm{~m}$ (Figure A1c). Video analysis recorded the relief of the seabed, and the presence and relative abundance of the major habitat forming flora and fauna, including algae Carpophyllum spp., Ecklonia radiata (C. Agardh) J. Agardh, articulated coralline algae Corallina $\mathrm{sp}$. (coralline turf), and encrusting coralline algae; sea urchins Evechinus chloroticus; and the sponges Cliona celata (Grant, 1826), Ancorina alata (Dendy, 1924), and Raspailia sp. 
(a)
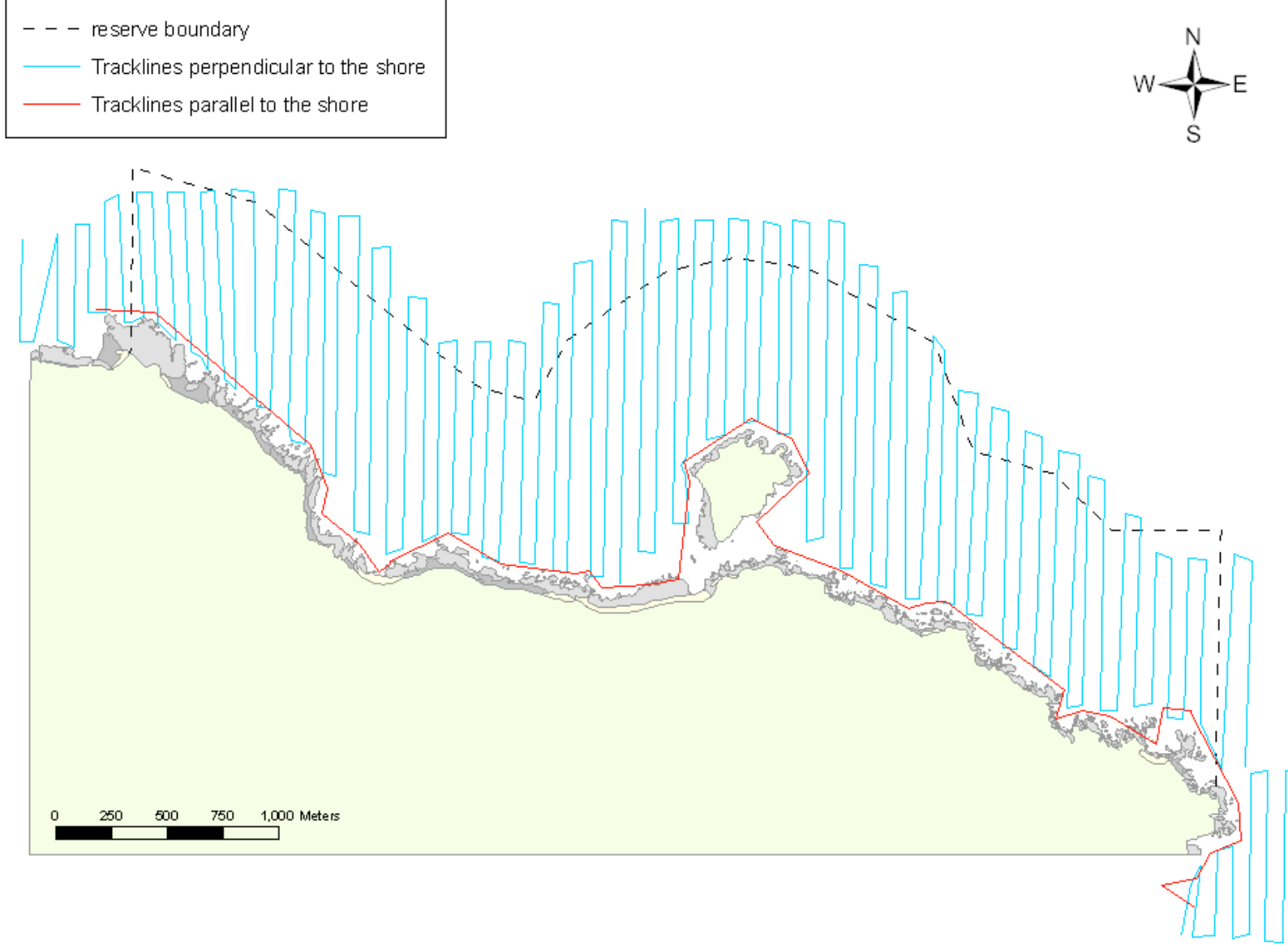

(b)

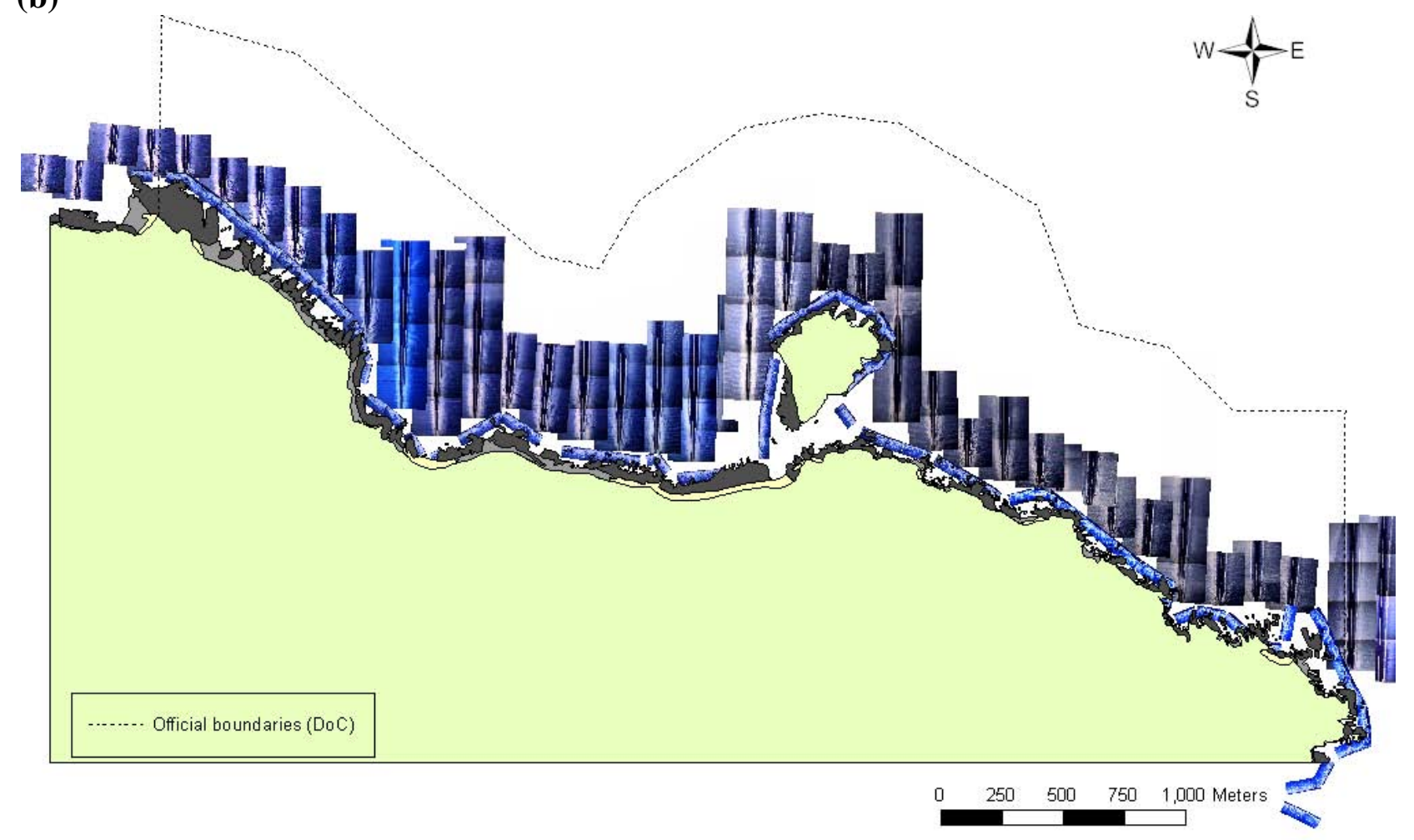


(c)

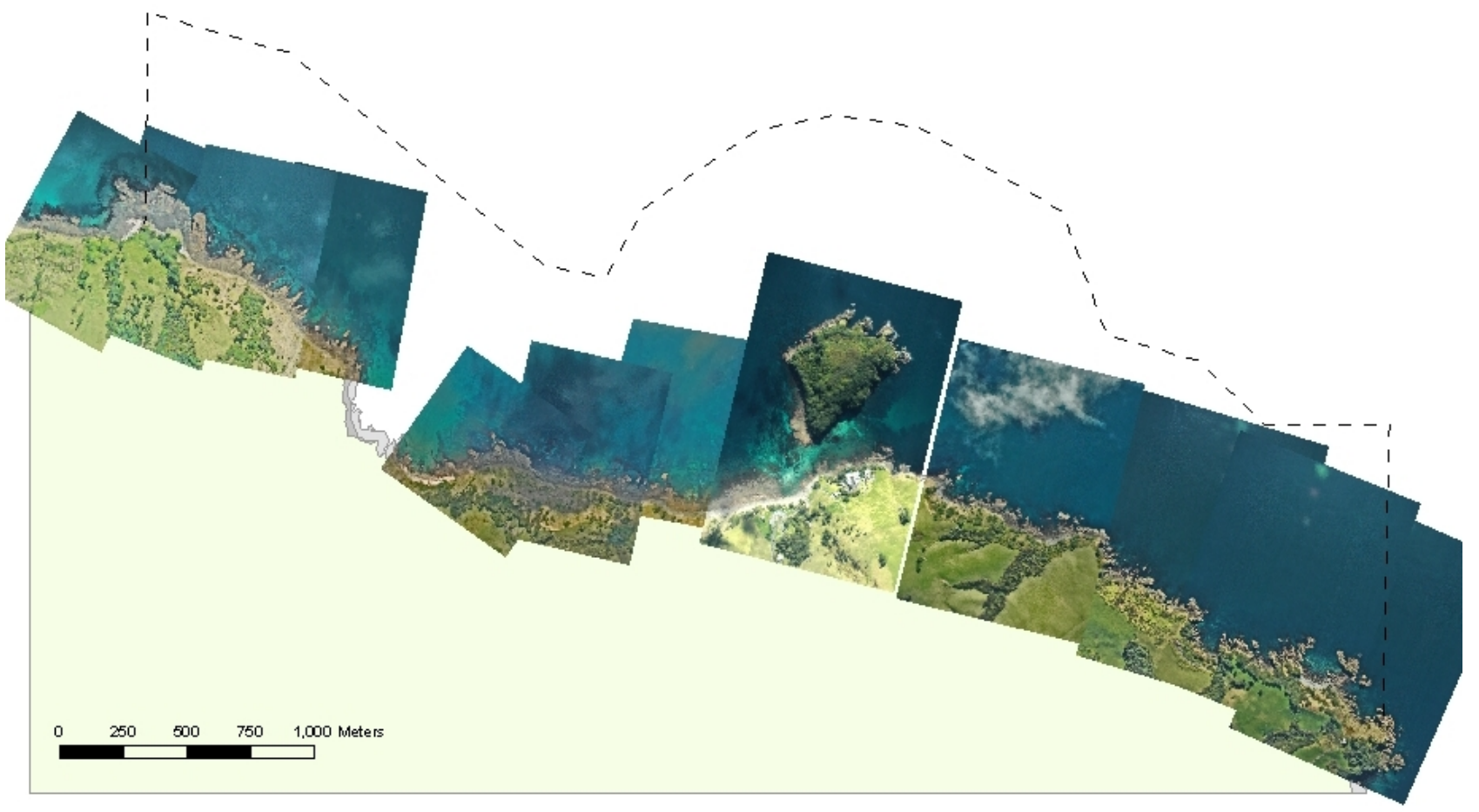

(d)

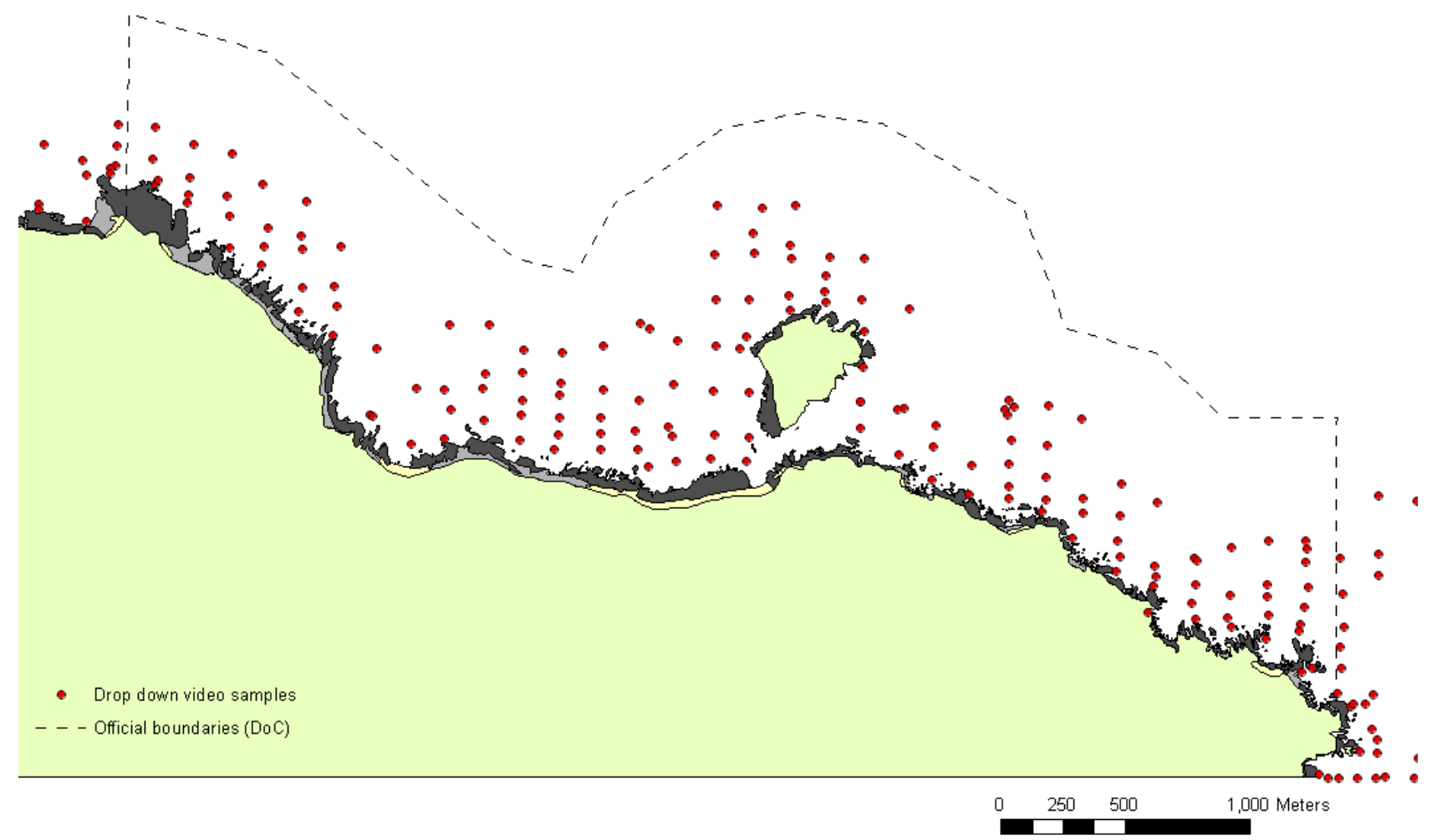

Figure A1. Map of the study area, showing the reserve boundaries (dashed lines), and (a) Side Scan Sonar transects (lines) and (b) images, (c) the aerial photographs, and (d) Drop Down Video sampling stations (dots). 